\title{
Da Oceania ao Cone Sul, da Nova Zelândia ao Rio Grande: desenvolvimento socioeconômico, produtividade sistêmica e a exploração de sinergias em cadeias agroindustriais de exportação
}

Carlos Águedo Paiva ${ }^{1}$

\section{Resumo}

Brasil e Austrália são dois países de passado colonial que apresentam territórios e especializações produtivas muito similares. O Rio Grande do Sul e a Nova Zelândia, idem. Não obstante, os países da Oceania apresentam indicadores de desenvolvimento econômico, social e humano muito superiores aos do Brasil e aos do Rio Grande do Sul. O objetivo deste trabalho é buscar as razões dessa diferença, com ênfase na comparação entre Nova Zelândia e Rio Grande do Sul. A conclusão à qual se chegou é que as principais determinações dos diferenciais de desempenho encontram-se no padrão de distribuição de renda (que rebate sobre o multiplicador interno das atividades de exportação) e no padrão de organização produtiva das cadeias exportadoras. Com vistas a aprofundar o segundo aspecto da questão, foi realizada uma análise detalhada do sistema de integração da pecuária de leite e de corte na Nova Zelândia, demonstrando as vantagens do sistema na diluição de custos fixos e ampliação da competitividade e rentabilidade sistêmicas. Por fim, procurou-se demonstrar que o padrão de organização do sistema pecuário neozelandês é perfeitamente replicável no Rio Grande do Sul.

Palavras-chave: Cadeia do leite. Cadeia da carne bovina. Oceania. Agropecuária.

\begin{abstract}
Brazil and Australia are two countries with a colonial past and which have very similar productive specializations and territories. The Rio Grande do Sul and New Zealand ditto. Nevertheless, the countries of Oceania have indicators of economic, social and human development much higher than Brazil and Rio Grande do Sul. The objective of this work is to find the reasons for this difference, with emphasis on the comparison between New Zealand and Rio Grande do Sul. The conclusion that was reached is that the main determinations of performance differentials are in standard income distribution (that bounces on the internal multiplier of export activities) and in the pattern of organization of productive chains exporters. With the objective of to deepen the second aspect of the question, we conducted a detailed analysis of the integration system of chain of milk and beef in New Zealand, demonstrating the advantages of the system in the dilution of fixed costs and increase competitiveness

\footnotetext{
${ }^{1}$ Economista, Doutor em Economia, professor do Programa de Pós-Graduação em Desenvolvimento Regional da FACCAT e pesquisador da FEE. carlosanpaiva@gmail.com
} 
and profitability systemic. Finally, we sought to demonstrate that the pattern of organization livestock system New Zealander is perfectly replicable in Rio Grande do Sul.

Keywords: Chain of Milk. Chain of beef. Oceania. Livestock.

\section{Introdução}

A Nova Zelândia e a Austrália apresentam um conjunto de similaridades com os países atlânticos do Mercosul - Brasil, Uruguai e Argentina -, a saber: 1) são excolônias; 2) estão localizadas no Hemisfério Sul; 3) estruturaram suas economias, desde o descobrimento até os dias de hoje, a partir de um número restrito de culturas agropecuárias e/ou mineradoras de exportação.

De outro lado, essas cinco economias apresentam um conjunto igualmente não desprezível de diferenças. Dentre elas, a mais notável - porquanto sintética de todas as demais - é que Nova Zelândia e Austrália são nações desenvolvidas, com elevadíssima renda per capita, padrão distributivo fortemente igualitário e excelentes indicadores de desenvolvimento humano. Já o Cone Sul é caracterizado por rendas per capita quatro vezes menores e indicadores inferiores de desenvolvimento humano (vide Quadro 1 do Anexo Estatístico).

Questionar (e sinalizar para) os determinantes da enorme diferença no grau e na qualidade do desenvolvimento socioeconômico desses 5 países, malgrado as marcantes similaridades produtivas, é o objetivo geral deste trabalho. Mas esse objetivo se desdobra em dois outros, mais específicos.

Em primeiro lugar, queremos entender os mecanismos pelos quais algumas cadeias produtivas agroindustriais - em particular a bovinocultura de carne e leite alcançaram os espetaculares níveis de produtividade que alcançaram nos países da Oceania.

Em segundo lugar, queremos identificar e hierarquizar os elementos do padrão de organização dessas cadeias, que diferem do padrão de organização das mesmas no Rio Grande do Sul. O critério de hierarquização das especificidades da 
organização produtiva dos países da Oceania é o seu grau de "replicabilidade": queremos identificar aquela(s) especificidade(s) que, se introduzida(s) em nosso território, garantiria(m) um máximo retorno por unidade de dispêndio e por unidade de tempo.

O desdobramento necessário dos nossos objetivos específicos compreende certa inflexão no objetivo geral, referindo-se à análise e à hierarquização das especificidades diferenciadoras das cadeias produtivas sob análise. Assim é que, a despeito de reconhecermos a absoluta centralidade da equação distributiva (da renda e da propriedade fundiária) na Oceania na determinação da qualidade e na produtividade das atividades rurais, ela não é o foco de nossa atenção. Assim como não o são os determinantes desse resultado: os distintos padrões e funções coloniais da América e da Oceania. Afinal, adotamos um critério econômico-pragmático de hierarquização de determinações, o que envolve tomar como determinação crucial aquela cujo enfrentamento gera o maior benefício por unidade de custo.

Qual o custo de impor qualquer modificação (por marginal que seja) na equação distributiva de uma nação, ou em seus padrões educacionais, ou no capital social acumulado, ou no "sistema nacional de inovação"? Que benefício se pode esperar dessa alteração para a alavancagem das taxas de crescimento? Qual é o benefício obtido por unidade de dispêndio? Existem movimentos de alavancagem da renda e da produtividade que podem ser impostos com menor custo por unidade de benefício? Em caso afirmativo, esse é o movimento que deve ser privilegiado. Só por isso, essa é a determinação que caracterizamos como "crucial". Além disso, essa é a determinação que queremos entender e para cuja conquista pretendemos contribuir, avaliando os custos de sua replicabilidade para os setores público e privado.

Este trabalho divide-se em cinco seções, além desta introdução. Logo abaixo, apresentamos alguns dos traços mais marcantes das economias neozelandesa e australiana e as comparamos com as economias dos três países atlânticos do Mercosul. Na seção seguinte, aprofundamos a comparação entre a economia da Nova Zelândia e o a economia gaúcha. Na quarta seção, apresentamos e discutimos algumas hipóteses acerca dos determinantes do diferencial de desenvolvimento dos 
territórios considerados e selecionamos a "determinação crucial" (de acordo com o definido acima), cuja análise iremos perseguir. $\mathrm{Na}$ quinta seção, apresentamos o principal resultado da nossa pesquisa: nossa representação do modelo neozelandês de integração das bovinoculturas de corte e leite. A opção em modelar esse sistema deve-se ao fato dele ser "típico" nos sentidos de Marx (tipo extremo, realidade empírico-histórica mais desenvolvida) e de Weber (tipo ideal, modelo heurístico de agentes que agem de forma racional com relação a fins e/ou com relação a valores e tradições). Contudo, da modelagem desse sistema pode-se (e deve-se!) extrair toda uma família de modelos de integração e exploração de sinergias em cadeias agroindustriais. Na sexta seção, voltada às considerações finais, apontamos para a necessidade de adotar e expandir o modelo neozelandês nas pecuárias gaúchas.

\section{Oceania X Cone Sul}

A Austrália e o Brasil têm quase o mesmo tamanho (pouco menos e pouco mais de 8 milhões de $\mathrm{km}^{2}$, respectivamente), PIBs similares e inserções similares no mercado mundial, seja no plano do valor das exportações, seja no plano dos produtos comercializados e no peso das commodities agropecuárias e minerais. Não obstante, a renda per capita australiana é cinco vezes e meia a renda per capita brasileira (vide Quadro 1 no Anexo Estatístico). Vale dizer: a produtividade do trabalho na Austrália é aproximadamente cinco vezes maior do que a produtividade no Brasil².

\footnotetext{
${ }^{2}$ A produtividade do trabalho é calculada com base na população ocupada e a renda per capita com base na população total. Mas esta última uma proxy razoável da população ocupada quando as economias se encontram em patamares similares e relativamente baixos de desemprego, como é o caso para o ano de 2008, para o qual temos dados oficiais. O cálculo preciso da produtividade do trabalho nos dois países poderia ser feito tomando os dados disponíveis sobre população ocupada. Eximimo-nos de fazê-lo por desconhecermos detalhes das metodologias nacionais de pesquisa sobre emprego e ocupação e suas respectivas abrangências dos mercados formal e informal. Além disso, as comparações dos PIBs nacionais são passíveis de questionamento quando os países adotam padrões de administração monetária e cambial distintas. Entendemos, assim, que o grau de confiabilidade em um indicador baseado em tantas variáveis coletadas em distintos países com distintas metodologias era muito pequeno, de sorte que os esforços necessários para seu cálculo não eram compensados pelos benefícios da informação gerada.
} 
A Nova Zelândia, por sua vez, parece-se muito com o Rio Grande do Sul. A área é praticamente a mesma: em torno de $280 \mathrm{mil} \mathrm{km}^{2}$. Algumas das mais importantes especializações produtivas são muito similares: leite, carne, lã, vinho e turismo. Mas a renda per capita neozelandesa é mais de três vezes a renda per capita gaúcha, de sorte que a produtividade nas cadeias produtivas dinamizadoras da economia deve ser, também, muito superior. Por quê?

Desde logo, o componente central da diferença não se encontra no grau de dependência das exportações como dinamizador da economia, ou no grau de dependência de produtos primários e minerais. Antes pelo contrário: aqui temos semelhanças. Onde há diferença, ela é apenas de grau. A diferença de grau vai ao sentido oposto ao usualmente pretendido: a dependência do Mercosul (malgrado o pequeno Uruguai) parece ser menor do que a dependência da Oceania da exportação de produtos primários. Todavia, nem por isso nossa autonomia real é maior do que a da Oceania: pelo menos, não a autonomia para internalizar, distribuir e acumular o excedente econômico gerado internamente.

A diferença que parece ser mais marcante e o substrato de todas as demais diferenças - por ser, simultaneamente, muito primitiva e capaz de gerar resultados nos mais diversos planos (do capital social ao tamanho do mercado) - refere-se à estrutura da distribuição da renda e da propriedade. Na verdade, a tese (de extração kaleckiana) de que o desenvolvimento capitalista seja alavancado por uma distribuição o mais equitativa possível do produto social entre trabalhadores assalariados (ou produtores familiares), empresários e proprietários dos meios de produção, que vem sendo defendida por nós em diversos trabalhos (PAIVA, 2004a, 2004b, 2004c, 2008a, 2008b, 2008c). Mas a sua comprovação empírica é mais complexa do que pode parecer.

Desde logo, os dados sobre concentração de renda são de difícil interpretação. Na realidade, são enormes as complexidades de qualquer comparação internacional de indicadores calculados por órgãos nacionais de estatística, com critérios e metodologias muito distintas. Felizmente, no plano da distribuição da renda, vimos contando com os esforços da Universidade da ONU e 
do professor Frederik Solt para compatibilizar metodologias e tornar comparáveis os índices de Gini da renda. O esforço já foi estendido a 137 países, dentre os quais se encontram os cinco países mencionados. Tomando a média dos índices de Gini calculados para os distintos países do mundo entre 1995 e 2004, o Brasil foi ranqueado como o sétimo país mais desigual do mundo, cuja estrutura de distribuição de renda é a sétima mais concentrada. A Austrália ocupou a centésima décima segunda colocação; a Nova Zelândia foi ranqueada como a nonagésima quinta nação mais concentrada; o Uruguai é o sexagésimo quinto colocado; a Argentina é a trigésima quarta dentre 137 nações (vide Quadro 1 do Anexo Estatístico) ${ }^{3}$.

No entanto, se a distribuição é a determinação crucial no sentido de mais primitiva e enraizada, ela não pode ser a determinação crucial no sentido pragmático-econômico que elegemos aqui. Afinal, a distribuição é um elemento estrutural, profundamente arraigado em um sistema produtivo. Essa é uma variável de pequena flexibilidade no curto prazo, sobre a qual não se pode incidir esperando obter resultados expressivos no curtíssimo prazo ${ }^{4}$. Por isso mesmo, entendemos que qualquer programa de desenvolvimento deve diferenciar e associar objetivos de curto e longo prazo. Trata-se, assim, de projetar ações que se articulem desde o curto prazo (no qual a prioridade é o programa emergencial de crescimento) até os objetivos de longo prazo: a melhoria estrutural da distribuição e a genuína universalização da cidadania.

Ora, se queremos acelerar o processo de redistribuição de renda, é preciso liberar ao máximo os recursos públicos para os gastos/investimentos sociais de

${ }^{3}$ Evidentemente, nenhum esforço de compatibilização de índices é suficiente para tornar números unidimensionais uma síntese acurada e expressiva do acesso real da população aos distintos bens públicos (segurança, integridade, etc.) e de consumo (alimento, roupa, abrigo) garantidos na declaração universal dos direitos do homem. A necessidade de avaliar o padrão de cidadania - de apropriação pública dos bens públicos pelos cidadãos - a partir de uma perspectiva antropológica do vivido, da experimentação total, foi um dos determinantes da decisão de visitar os dois países. Voltaremos a esse ponto oportunamente.

${ }^{4}$ Por isso mesmo, não pode ser tomada como a "determinação crucial", no sentido econômicopragmático que abraçamos aqui. Da mesma forma, não podemos tomar as profundas diferenças no padrão de ocupação e colonização ibérica e anglo-saxã, e seus desdobramentos nos planos da cultura, das instituições, do sistema nacional de inovações e/ou da comunidade cívica como "determinações a serem enfrentadas". Essas são variáveis estruturais, e o enfrentamento de seus desdobramentos culturais contemporâneos é um trabalho penoso e que só tende a frutificar se devidamente apoiado em um longo processo de acumulação material. 
grande impacto na estrutura da distribuição. Isso envolve atribuir à iniciativa privada a função de financiamento e custeio dos dispêndios (de insumos e/ou investimentos) necessários à retomada imediata do crescimento econômico ${ }^{5}$, de sorte que nossa pesquisa se voltou para a identificação das especificidades das economias australiana e neozelandesa que podem ser introduzidas no RS (e no Brasil, e no Mercosul) pelo setor privado, com base na lógica do ganho privado. Assim, o ponto de partida desta análise é a identificação das similaridades e diferenças nas estruturas produtivas.

Como se sabe, um país (e uma região) exporta os bens e serviços nos quais é (relativamente) mais competitivo. Além disso, torna-se mais competitivo naqueles segmentos em que a divisão do trabalho e as escalas são suficientemente elevadas para gerarem significativas economias internas e externas. Em suma: exportação, especialização, escala e produtividade são as quatro faces de uma mesma pirâmide triangular. Nosso ponto de partida da análise da estrutura produtiva dos cinco países é, pois, suas balanças comerciais (Quadros 2 a 6, do Anexo Estatístico).

Desde logo, as balanças comerciais de Austrália e Nova Zelândia apresentam inúmeras similaridades. Ambas apresentam discreto déficit comercial. Em ambos os casos, o discreto déficit está associado ao fato de que o saldo positivo das primeiras alíneas da Balança Comercial - Alimentos, Matérias Primas e (no caso da Austrália) Combustíveis e Lubrificantes - ser inferior ao saldo negativo das 4 alíneas seguintes Produtos Químicos, Bens Manufaturados, Maquinaria e Material de Transporte $^{6}$ e Produtos Diversos ${ }^{7}$. Em suma: o que pautas e saldos revelam é que Austrália e Nova

\footnotetext{
${ }^{5} \mathrm{Na}$ medida em que esses investimentos gerarão benefícios para todos, o seu custeio pela iniciativa privada já envolve (e resulta em) melhoria na distribuição da renda. Por isso mesmo, não cabe ao Estado subsidiar a iniciativa privada e financiar seus lucros. Fazer isso é financiar o investimento privado com recursos públicos, é repassar dinheiro do povo para alguns poucos particulares. Cabe ao Estado tão somente orientar a iniciativa privada e prestar serviços públicos gratuitos à população que deles necessita. Além disso, a orientação a ser dada a iniciativa privada é apontar o caminho que maximiza o ganho privado e garante um ganho social superior à mera soma dos ganhos privados e demonstrar, com palavras e atos, que esse caminho terá o apoio do Estado.

6 Vale notar que essa alínea: 1) concentra os equipamentos nos quais se consubstanciam os investimentos privados e públicos; 2) é responsável por mais de um terço das importações nos dois países.

7 A alínea final é "outros" e se refere, essencialmente, a ouro não monetário e a demais ativos que cumprem funções financeiras. Como Austrália, Brasil e Nova Zelândia (secundados, a grande distância, pela Argentina e Uruguai) são exportadores de ouro, há saldo positivo nessa conta.
} 
Zelândia são economias produtoras de alimentos e matérias-primas que importam parcela expressiva de bens industrializados, mormente máquinas e equipamentos.

Não surpreenderá, pois, que as pautas de Brasil, Argentina e Uruguai revelem realidades similares, ainda que haja um gradiente: o Uruguai é ainda mais especializado em produtos agropecuários do que a Oceania. Enquanto Brasil e Argentina são menos especializados. Quase três quartos das exportações uruguaias estão referidas a alimentos e a matérias-primas (as Alíneas 1 e 2 da Balança Comercial), enquanto que, no caso do Brasil e da Argentina, mesmo com a inclusão da terceira alínea (Combustíveis e Lubrificantes), não se atingem os 60 por cento do valor exportado. No caso da Austrália e da Nova Zelândia, as três primeiras alíneas respondem por mais de dois terços das exportações. A Argentina e o Brasil também se caracterizam por superávits não desprezíveis em suas balanças comerciais (superiores a 10 bilhões de dólares na Argentina e superiores a 20 bilhões no Brasil).

Como se sabe, a posição da balança comercial também é um índice de evolução do poder de compra das moedas, na medida em que saldos positivos em tradeables usualmente estão associados a moedas relativamente desvalorizadas e vice-versa. Ainda que essa regra não seja, de forma alguma, geral ${ }^{8}$, ela já era indicativa de que a capacidade exportadora da Nova Zelândia e da Austrália não se explica pela política cambial desses países. A competitividade deles não é primariamente "chinesa": não é cambial, nem salarial.

Ela também não é "natural" em nenhum sentido. O ecossistema australiano é extremamente pobre e frágil. Nem por isso a Austrália deixa de ser uma grande exportadora de commodities agropastoris. É bem verdade que, atualmente (e durante o fugaz ciclo do ouro), a Austrália extrai(u) da mineração a maior parte de suas divisas. Esse é um mercado de big players. Mas a história da Oceania não é a

${ }^{8}$ Essa é mais uma determinação de nossa opção de "imersão antropológica". Entendemos que a literatura sobre paridade do poder de compra (PPP) é demasiado viesada para o acompanhamento da evolução das relações de intercâmbio e dos níveis de preços do que para a avaliação (mais complexa e mais importante) do patamar de sobrevalorização ou subvalorização inicial. Arbitra-se o início e postula-se que, no início, havia equilíbrio. Por quê? Porque é mais simples. Só por isto. O que torna a literatura muito pouco informativa, de fato. Do meu ponto de vista, o patamar de valorização de uma moeda só é realmente "apropriado" com a ambiência e o compromisso cotidiano do pesquisador de dispêndio (e comparação com os gastos equivalentes em seu país) no mercado de bens e serviços das principais cidades do país sob investigação. 
história dos big players da mineração - ou não teria a distribuição de renda que tem. De forma particular, a história da Nova Zelândia não é a de big players em geral. Trata-se de um território que - já o dissemos - se assemelha muito ao Rio Grande do Sul e ao Uruguai. Avaliemos essas semelhanças.

\section{Nova Zelândia (e Uruguai) X Rio Grande do Sul}

Nova Zelândia e Rio Grande do Sul têm aproximadamente o mesmo tamanho. O Uruguai é em torno de $100 \mathrm{mil} \mathrm{km}^{2}$ menor. De outro lado, Nova Zelândia e Uruguai se aproximam mais no que diz respeito ao padrão de especialização produtiva. A estrutura produtiva do Rio Grande do Sul parece ser mais diversificada, e o peso relativo das exportações dos subprodutos das cadeias produtivas já referidas - bovinoculturas corte/leite, ovinoculturas lã/carne - é significativamente menor para o RS. A importância relativa dos principais sub-produtos destas cadeias - de animais vivos a queijos - para os cinco países considerados e o RS é sistematizada nos Quadros 8 e 9 do Anexo Estatístico. O que se observa aí é que, enquanto o trinômio carne/leite/lã é responsável por cerca de um terço das exportações da Nova Zelândia e do Uruguai, ele não chega a 12 por cento do valor das exportações do Rio Grande.

Antes que se possa interpretar adequadamente essa diferença, contudo, é preciso introduzir uma pontuação metodológica importante: a balança comercial de uma região com o exterior da nação (que é menor que o exterior da região) não espelha bem a especialização produtiva e o perfil exportador regional. $O$ que a região exporta para outras unidades da federação também é especialização exportadora. Mas essa especialização não se manifesta no tipo de "balança comercial" do Rio Grande do Sul que o sistema Alice (um sistema nacional) proporciona. A maior parte das exportações gaúchas de lácteos se faz para os outros Estados do país. Posto isso, vale observar algumas similaridades e diferenças nas Balanças de Comércio Exterior do RS e dos dois países com os quais o confrontamos. 
Tal como o Brasil, o RS é um pouco menos dependente de exportações de alimentos e matérias-primas para o exterior do que a Nova Zelândia e o Uruguai. Estas duas primeiras alíneas representam 52,2 por cento das exportações do RS em 2009 , e representavam 73,6 por cento e 62,6 por cento das exportações do Uruguai e da Nova Zelândia, respectivamente. De outro lado, o RS aproxima-se mais do valor total exportado por NZ do que o parceiro merco-sulino: 25 bilhões de dólares para a Nova Zelândia, 5,4 bilhões de dólares para o Uruguai e 15,2 bilhões de dólares para o Rio Grande do Sul.

Parte dessa competitividade gaúcha é induzida pela articulação do RS com o amplo mercado nacional e pelas políticas industriais do governo federal no passado. Esse é o caso da petroquímica, responsável por 20 por cento das exportações gaúchas. Mas grande parte da diversificação industrial gaúcha parece ser genuinamente "local". Isso porque emergem outros indícios de diversificação competitiva que não parecem explicáveis por políticas públicas de atração de investimentos; como, por exemplo, os superávits não desprezíveis do RS nas alíneas "Bens Manufaturados" e "Diversos". Vale lembrar que esses são segmentos que abrigam a maior parte das indústrias de entrada livre ou "facilitada". Via de regra, são indústrias tradicionais locais, usualmente subvalorizadas (não fomentadas, ou apenas marginalmente), pois elas teriam origens e raízes no "passado agropastoril" do Estado, sendo percebidas como instituições de certo passado, do RS produtor de banha, de suínos,charque, couro e arroz. A competitividade desses setores não parece ser "bênção pública". Há aí, pois, indícios de competitividade adquirida e consolidada em cadeia. Há que se investigar.

Não acreditamos, contudo, que a maior diversidade produtiva gaúcha aparente na análise da Balança Comercial Exterior do Rio Grande do Sul comprometa o reconhecimento da grande importância das cadeias produtivas bovinoculturas e ovinoculturas selecionadas. Até porque essas cadeias, no caso do RS, perpassam as alíneas: boa parte do saldo gaúcho positivo na alínea "Manufaturados" está associada à exportação de calçados. O setor coureiro se originou da pecuária; é uma típica agroindústria gaúcha. Mas, hoje, mobiliza o setor químico (cola) e plásticos 
(solado, couro sintético), impacta em maquinaria (há toda uma indústria de máquinas para calçados no RS), papel e papelão (embalagem) e mobiliza um complexo sistema de serviços de logística. Isso porque timing é tudo em "moda".

Por isso mesmo, avaliar a importância de uma cadeia produtiva no interior da economia de um dado território pressupõe acessar essa economia de diversas perspectivas, resgatando os desdobramentos dos distintos elos das cadeias de uma economia. Vamos começar esse resgate pela Balança Comercial Total do RS, que pode ser obtida para o ano de 2003 em função da Matriz de Insumo Produto produzida pela FEE (esse é o último ano para o qual há informações sistematizadas e balanceadas deste quesito). Essa Balança Comercial está disponibilizada como Quadro 10 do Anexo estatístico.

O primeiro a observar é que adotamos um critério particular de agregação dos segmentos econômicos com vistas a obter informações sobre as cadeias que estão no foco de nossa análise. A partir das Tabelas de Recursos e Usos (Tabelas 3 e 4) da MIP-RS-2003, obtivemos os valores importados do exterior e dos demais estados da federação, bem como os valores exportados para o exterior e para os demais estados da federação de 8 segmentos produtivos assim definidos: 1) agroindústria "neozelandesa", que inclui os setores de laticínios, carnes, couros, fiação e tecelagem, e bebidas (fundamentalmente vinhos); 2) outras agroindústrias, que incluem os grãos e óleos (arroz, soja, milho e trigo), madeira/celulose/papel/mobiliário, fumo e cigarros e outras indústrias agroalimentares; 3) Mineração, metalúrgica, mecânica, material elétrico e de transporte; 4) borracha, químico e plásticos; 5) produtos diversos; 6) construção civil; 7) serviços industriais de utilidade pública; 8) comércio, serviços e administração pública. Como podemos ver no Quadro 10 (Anexo Estatístico), todo o saldo comercial com o exterior é obtido a partir dos dois segmentos em que dividimos as agroindústrias: o segmento "neozelandês" caracterizado por operar com matérias-primas pecuárias e por uma elevada 
agregação de valor sobre as matérias-primas; e o segmento "outros", que é caracterizado pela hegemonia dos grãos e óleos, fumo e madeira/celulose ${ }^{9}$.

Com base na mesma fonte de informação - as Tabelas de Recursos e Usos da MIP 2003 - montamos um quadro com a participação desses mesmos setores no PIB. Os dados encontram-se sistematizados no Quadro 11 (Anexo EWstatístico), disponibilizado no mesmo Anexo. Aqui, a informação mais relevante é o fato dos dois segmentos sobre os quais incide a maior demanda total - metal-mecânico e químico-plástico -, com 69,6 e 66,9 bilhões de reais, respectivamente, como consumo intermediário e demanda final, contribuírem relativamente tão pouco para o PIB regional - 9,3 e 4,8 bilhões de reais, respectivamente. De outro lado, chama a atenção o peso das Agroindústrias. Em conjunto, os dois grupos de agroindústria são responsáveis por mais de 40 por cento do PIB. Mas, sem dúvida, o peso maior se encontra nos grãos e óleos (13,21 por cento). Têxteis, vestuário e calçados vêm na sequência (7,27por cento do PIB); seguido pelo setor de carnes $(6,76$ por cento do PIB), fumo (3,85 por cento do PIB). Os lácteos perfazem o menor segmento agroindustrial, com 1,37 por cento de contribuição ao PIB.

Sem dúvida, os dados acima revelam que a agroindústria gaúcha estrutura-se de forma distinta em relação à neozelandesa, com um peso maior para os segmentos exportadores agrícolas e/ou com agregação de valor relativamente menor (grãos, tabaco, madeira) do que nos segmentos pecuários e/ou com agregação de valor maior (lácteos, carnes, fios, têxteis, calçados, vinhos). Não obstante, eles não são suficientes para induzir a qualquer privilégio do segmento relativamente maior vis-à-vis ao segmento "neozelandês". São, por isso, dois motivos articulados.

\subsection{Mercado e competitividade}

\footnotetext{
${ }^{9}$ Tal como defendemos em outros trabalhos (mormente em Paiva, 2008c), os grãos (cuja maior parte é exportada a granel), o tabaco (exportado seco e prensado) e a madeira/celulose (excetuados o segmento de móveis) são cadeias relativamente curtas, com fracos estímulos à agregação de valor e à diversificação urbanas. Do nosso ponto de vista, para além da boa distribuição da propriedade e da renda, o sucesso neozelandês está referido aos segmentos nos quais o país se especializou: segmentos de cadeia longa, que exigem agregação de valor e diversificação produtiva urbana antes de serem exportados.
} 
Em primeiro lugar, é preciso avaliar as tendências e perspectivas de mercado. Nesse quesito, os dados empíricos são muito claros. Segundo Lazzari (2010, p. 18), no período de 1981 a2009,

[...] a expansão da agropecuária gaúcha foi de 2,3 por cento ao ano, em média, ficando abaixo da taxa brasileira, que foi de 3,2 por cento no período. [...] Com a exceção do arroz, todos os outros grãos perderam participação, notadamente milho e soja. [...] $\mathrm{Na}$ pecuária, os rebanhos bovinos, suínos e frangos do Rio Grande do Sul também perderam participação nos rebanhos brasileiros; apenas o leite ganhou espaço entre 1980 e 2008.

Ora, tomamos o crescimento da participação relativa do RS no mercado brasileiro do leite entre 1980 e final desta primeira década do século XXI como a demonstração cabal de nossa competitividade no setor. Afinal, ao longo desse período, emergiram e consolidaram-se como produtores agropecuários um grande número de UFs que, no início do período (década de 1980), ainda contavam com fronteira agrícola aberta. Isso significa dizer que a perda relativa de participação do RS na produção agropecuária era esperada e poderia ser, mesmo, universal. Mas não o é. Ampliamos nossa participação no leite porque apresentamos vantagens competitivas estruturais no segmento. A começar pela estrutura fundiária da Metade Norte e parcela da Metade Sul, que é consistente com atividades intensivas em trabalho, como a produção leiteira. A grande competitividade do RS no setor é alvissareira nesse momento caracterizado pela expansão acelerada do mercado interno (capitaneado pelo crescimento da demanda "nova classe média") e do mercado externo, com o acelerado crescimento da demanda asiática.

Vale observar que o mercado internacional de lácteos já é significativo: o valor das exportações mundiais de leite superou os valores das exportações globais de carne bovina em 2008 e são similares a esses valores em 2009. Já os valores das exportações mundiais de leite, manteiga e queijos superaram os valores das exportações globais de "outras carnes", atingindo quase 70 bilhões de dólares no ano de 2008.

Além disso, é um mercado relativamente desconcentrado. A Nova Zelândia tem uma participação proeminente, mas não indisputável nesse mercado. O país é 
apenas o segundo maior exportador de leite ${ }^{10}$ e não é responsável sequer por 12 por cento do valor total das exportações. Se a participação da Nova Zelândia no mercado de manteiga é maior (20 por cento), a participação no mercado de queijos - hegemonizado pela França - é significativamente menor (em torno de quatro por cento). No conjunto do segmento "lácteo", a Nova Zelândia ocupa menos de dez por cento do mercado. Como esse é um mercado em acelerada expansão mundial, e a Nova Zelândia opera com taxas elevadas de produtividade e já esgotou sua fronteira agrícola, não parece haver muitos riscos no prognóstico de que a participação desse país no mercado mundial deve declinar nas próximas décadas.

Em suma: a Nova Zelândia disputa com a Alemanha e a França (e países do entorno, mormente Holanda e Dinamarca) o papel de "principal player" no setor lácteo. Cada um dos principais players conta com algo em torno de dez por cento do mercado. A França hegemoniza nos queijos; a Nova Zelândia, na manteiga; a Alemanha, no beneficiamento de leite. A Nova Zelândia exporta em torno de seis bilhões de dólares ano no segmento. O Uruguai exporta US\$ 397 milhões e bate o Brasil, que exporta US\$ 329 milhões (US\$ 42 milhões a partir do RS). Brasil e Uruguai, juntos, ocupam menos de 1,2 por cento do mercado mundial.

\subsection{Integração "para trás", cadeias produtivas e territorialidade}

Como sabemos, a importância de um setor diz respeito não apenas a ele mesmo, diretamente, mas a seus encadeamentos a montante, expressos no multiplicador "para trás" (backward linkages) do setor. De acordo com Porsse, dentre 40 setores produtivos da economia gaúcha, os seis que apresentavam maior multiplicador para trás em 2003 (ano da última MIP produzida no RS) eram, em ordem: 1) fabricação de óleos vegetais; 2) abate de animais; 3) indústria de

${ }^{10}$ O primeiro é a Alemanha, que, contudo, também é o maior importador mundial. Se tomarmos o saldo líquido, a Nova Zelândia assume o primeiro posto, deslocando a Alemanha para a segunda colocação. A esse respeito, veja-se http://comtrade.un.org/db/ce/ceSnapshot.aspx?px=H1\&cc=04. 
laticínios; 4) beneficiamento de produtos vegetais; 5) fabricação de calçados; 6) indústria do fumo; 7) outros produtos alimentares, inclusive rações ${ }^{11}$.

Além disso, as cadeias de leite e carne (bem como lã e couro) não devem ser tomadas separadamente. Como bem o demonstra o padrão neozelandês de integração de cadeias (a quinta seção deste trabalho é totalmente dedicada ao tema), muito se ganha em termos de produtividade e competitividade dessas cadeias quando elas são pensadas de forma integrada. Se as tomamos assim, o primeiro bloco de agroindústrias (no interior do qual, se encontra os subgrupos lácteos) é bastante expressivo, responsável por quase 20 por cento do PIB do Estado.

Como se isso não bastasse, a importância de uma cadeia também deve ser pensada em termos de sua territorialidade. As cadeias agroindustriais de leite e de carne encontram-se enraizadas em absolutamente todo o território gaúcho, envolvendo da capital (Porto Alegre) ao mais recôndito rincão interiorano. Trata-se de um enraizamento que já se revela no fato de que 46,47 por cento dos estabelecimentos agropecuários do RS produziram leite em 2006 (ano do último Censo Agropecuário), enquanto essa percentagem foi de 26,07 por cento para o Brasil como um todo (vide Quadro 12, no Anexo Estatístico). Mais: 60,07 por cento dos estabelecimentos pecuários e 42,01 por cento dos estabelecimentos cuja atividade principal é a "lavoura temporária" produziram leite (contra meros 42,66 e 14,64 por cento no Brasil como um todo). Vale notar ainda que o número de estabelecimentos agropecuários no RS corresponde a 8,53 por cento do total brasileiro, mas contamos com 15,2 por cento dos estabelecimentos produtores de leite do Brasil. Nossa produção é 1,57 vezes maior (por unidade vacum) do que a brasileira e o RS detém 31,39 por cento dos estabelecimentos nacionais com

${ }^{11}$ Os setores com maior multiplicador para trás, no estudo da MIP-98, eram muito similares, a saber: 1) abate e preparação de carnes; 2) óleos vegetais e gorduras; 3) leites e laticínios; 4) beneficiamento de produtos vegetais; 5) indústria química; e 6) calçados, couros e peles. Vale observar que o segmento com maior integração para trás na MIP-2003é o setor de "fabricação de óleos vegetais"; e não a produção de grãos oleaginosos. A diferença tem que ser explicitada na medida em que apenas 18,54 por cento do valor da produção de grãos no RS é canalizado para a produção de óleo. O restante é exportado a granel (soja e milho), ou é seco e ensacado (arroz), ou processado como farinha (trigo). 
tanques para resfriamento de leite. Eles estão presentes em 45.699 estabelecimentos gaúchos ${ }^{12}$ e em 145.595 estabelecimentos em todo o país.

Aqui - finalmente - chegamos ao ponto em relação à importante indústria metal-mecânica gaúcha e as agroindústrias. O RS é responsável por 12,18 por cento do leite produzido no país, mas contamos com 31,39 por cento dos resfriadores, cuja capacidade de armazenamento corresponde a 18,86 por cento da capacidade nacional. Em suma: nosso produtor é mais "tecnificado", mas o tamanho médio do resfriador é menor do que nos demais estabelecimentos do país. Por quê? Por dois motivos: 1) o produtor de leite gaúcho é, essencialmente, o agricultor familiar, com uma produção individual relativamente pequena; 2) a produção de laticínios no RS - como, aliás, toda a produção agropecuária gaúcha - é fortemente integrada com a indústria fornecedora de insumos mecânicos, que é, ela mesma, uma agroindústria autônoma.

\section{Agropecuária, exportação e acumulação capitalista}

Tal como anunciamos na primeira seção deste trabalho, a grande questão que se coloca à nossa frente é: como Austrália (até meados do século $X X$ ) e Nova Zelândia (até os dias de hoje) alcançaram se transformar em economias desenvolvidas a partir de uma especialização produtiva tão peculiar: uma espécie de "oligo-cultura agropecuária de exportação" com dois braços: a bovinocultura corte/leite e a ovinocultura lã/carne? A questão de fundo é que - não contando esses países com Departamentos de Bens de Capital (doravante, D1) internalizados - a taxa de acumulação desses países ficou subordinada (e determinada) pela taxa de expansão das exportações agropecuárias. Isso ocorreu por dois motivos:

12 Do nosso ponto de vista, este é a informação que reflete de maneira mais fidedigna o "número de produtores rurais de leite" no RS. Afinal, nenhum produtor rural pode ter o leite como a (ou uma das) atividade(s) econômica(s) principal(is) se não possuir um resfriador. Se estendemos este critério para o Brasil como um todo e tomamos a percentagem da capacidade como expressão do comprometimento com a produção para a indústria, chegamos à conclusão que o RS é responsável por pouco menos de $1 / 5$ da produção nacional. 
1) Sem um $D 1$ consolidado internamente, a única variável de demanda autônoma capaz de impulsionar a reprodução ampliada da economia de forma sustentável passa a ser as exportações, nesse caso, assumindo-se que as principais cadeias exportadoras são as duas pecuárias.

2) Trata-se de duas cadeias que definem o montante de lucro do sistema, pois esse é igual ao valor agregado do "Departamento de Exportação".

É fácil perceber que as duas assertivas acima são estritamente kaleckianas. A primeira assertiva baseia-se na hipótese de que, em economias pequenas - como a neozelandesa e a australiana - é impossível endogeneizar mais do que uma parcela relativamente menor da produção de bens de capital. De sorte que a maior parte dos estímulos de demanda associados ao investimento são externalizados, impondo-se, efetivamente, no interior da economia dos países produtores e exportadores de bens de capital para a periferia e não no interior da economia periférica agroindustrial. Além disso, os gastos do governo ou são cobertos pelos impostos e, portanto, não geram lucro, ou o governo é deficitário, e o lucro conquistado é fictício e irrealizável em termos reais na ausência de superávits compensatórios posteriores. Em suma: no longo prazo, o orçamento tem que ser "equilibrado"; o que implica dizer que essa não é uma fonte sustentável (mas eventual) de geração de lucro. Só restam, assim, as exportações como fonte de demanda autônoma e de lucro.

Só não reconhecem essa tautologia aqueles que tomam equivocadamente o saldo das exportações e não as exportações brutas como variável de demanda autônoma sujeitam à multiplicação e aceleração ${ }^{13}$. Mas é relativamente fácil superar essa dificuldade analítica. Se não vejamos:

$$
\text { 1) } Y d=C w+C k+I+(G-T)+X-M=P+W \text {; }
$$

Em que $\mathrm{Yd}=$ renda disponível; $\mathrm{Cw}=$ consumo dos trabalhadores; $\mathrm{Ck}=$ consumo capitalista; $I=$ investimento; $G=$ gastos do governo; $T=$ tributação; $X=$ exportações; $\mathrm{M}=$ Importações; $\mathrm{P}=$ lucros brutos; $\mathrm{W}=$ massa de salários.

\footnotetext{
${ }^{13}$ Da multiplicação, emergem as demandas subordinadas de consumo e de investimento em estoques. $\mathrm{Da}$ aceleração, emergem investimentos em capital fixos requeridos para a adequação da relação capital/produto com a queda sistemática da capacidade ociosa.
} 
$\mathrm{Se}$

2) $\mathrm{Cw}=\mathrm{W}$;

Vale dizer: os trabalhadores (enquanto classe, não enquanto indivíduos: a poupança de uns equivale à "despoupança" de outros) não poupam. Se

3) $\mathrm{Ck}+\mathrm{I}=\mathrm{M}$;

Vale dizer: as importações não apenas são equivalentes em valor, mas se consubstanciam objetivamente em bens de consumo de luxo e em bens de capital (de sorte que os estímulos dessas variáveis da demanda autônoma é integralmente externalizada). Se:

$$
\text { 4) } M=X \text {; }
$$

Vale dizer: não há déficit nem superávit comercial. Além disso, se:

$$
\text { 5) } G=T \text {; }
$$

Vale dizer: o orçamento é equilibrado. E então:

$$
\text { 6) } P=(C k+I-M)+(G-T)+X=0+0+X \text {; }
$$

Ou seja,

$$
\text { 7) } P=X
$$

Mas se os lucros são determinados pelo (e, no limite, equivalem ao) valor das exportações, três questionamentos se impõem:

1) Como países ex-coloniais, produtores das mesmas commodities agrícolas de baixo valor agregado que caracterizam a produção de mais de 50 por cento da área rural gaúcha (bovino e ovinocultura), atingiram um elevado grau de desenvolvimento econômico-social? 
2) Por que a maior parte do território gaúcho, em especial aquela porção cuja matriz produtiva é muito similar à da Nova Zelândia e do Sudeste australiano (Metade Sul), vem apresentando uma performance econômica e indicadores socioeconômicos tão inferiores às regiões coloniais-industriais do RS e às economias australiana e neozelandesa?

3) Qual é o diferencial do padrão produtivo neozelandês (e australiano) que torna uma especialização produtiva perversa para nós, uma especialização produtiva alavancadora do bem-estar econômico dos mais diversos estratos sociais?

Nós tínhamos conosco algumas hipóteses. A mais básica e elementar é que a distribuição da renda e da propriedade nos dois maiores países da Oceania alavanca o multiplicador (diretamente) e o acelerador (indiretamente, via elevação sustentada do nível de utilização da capacidade instalada) da economia. Além disso, o desdobramento (quase) necessário de um mercado interno maior e de uma taxa de investimento mais elevada é a agregação de valor nas cadeias exportadoras e a diversificação das atividades não-exportadoras. Essa hipótese também é facilmente demonstrável, se assumimos o referencial teórico kaleckiano. No caso, admitindo-se que:

$$
\text { 8) } w=W / Y d
$$

Vale dizer, admite-se que "w" seja a participação dos salários na renda e que essa relação seja bastante estável no curto prazo. Admitindo-se as demais relações anunciadas anteriormente em (1) e (2), temos que

$$
\begin{aligned}
& \text { 9) } Y d-w^{*} Y d=P=(C k+I-M)+(G-T)+X ; e \\
& \text { 10) } Y d(1-w)=P=X ; \text { onde } \\
& \text { 11) } Y d=X /(1-w) .
\end{aligned}
$$

Em suma: dado o valor das exportações, a renda nacional será tão maior quanto maior for a "w", a participação dos salários na renda. A relação entre 
distribuição e nível de renda diz respeito à elevada propensão a consumir da classe trabalhadora (que, por hipótese, no modelo kaleckiano, é de 100 por cento).

Mas o problema efetivamente complexo é outro: uma vez que o investimento não é variável de demanda autônoma relevante em economias agrícolas relativamente pequenas (em termos do mundo) e altamente especializadas, a taxa de crescimento do sistema é função da taxa de crescimento das exportações. Ou, em termos algébricos, se (11) é verdade, também é verdade que, dada uma certa distribuição da renda, "w":

$$
\text { 12) } \Delta \mathrm{Yd}=\Delta \mathrm{X} /(1-\mathrm{w})
$$

De sorte que a taxa de crescimento das economias neozelandesa (ainda hoje) e australiana (no passado recente) foi determinada pela taxa de crescimento de suas exportações agropecuárias. Como foi possível ampliar de forma sustentada o mercado externo para leite, carne e lã? Austrália e Nova Zelândia não enfrentaram restrições às suas exportações de produtos primários por parte dos EUA, Europa e países asiáticos desenvolvidos? Certamente, sim, de forma que a expansão sustentada de exportações agrícolas só pode se basear em uma competitividade externa extraordinária.

Quando iniciamos a investigação, tínhamos duas hipóteses para essa competitividade extraordinária: 1) moeda cronicamente subvalorizada; 2) aproveitamento inovador das sinergias internas às duas principais cadeias agroindustriais de exportação.

A primeira hipótese mostrava-se relativamente frágil por indicadores já referidos; em especial o discreto - mas persistente - déficit comercial australiano e neozelandês. Mas não entendemos possível negar tal hipótese apenas com base na literatura consolidada, seja porque as medidas de "paridade de poder de compra" são cronicamente insatisfatórias e instáveis, seja porque há uma grande distância entre a política anunciada, teorizada e experienciada/percebida pela população-alvo. Uma certa imersão "antropológica" nos parecia essencial para uma percepção mais qualificada dos preços relativos (mormente entre tradeables e não-tradeables), do 
padrão cambial e das políticas públicas percebidas pelos agentes situados em distintos elos das cadeias produtivas exportadoras.

Além disso, queríamos ter acesso à literatura polêmica e heterodoxa sobre a economia do país. Trata-se de uma literatura que é tão vasta quanto diversificada em termos de consistência teórico-analítica, que tem de ser "garimpada", portanto. Isso pressupõe o acesso a bibliotecas e a livrarias especializadas nas economias australiana e neozelandesa. Em suma: o teste de hipótese pressupunha uma visita aos países investigados. A metodologia de pesquisa envolveu, pois, um deslocamento à fonte, com uma imersão "antropológica" no objeto.

Desde logo, a hipótese câmbio foi integralmente rechaçada com a visita aos dois países realizada em dezembro de 2010. As políticas monetárias e cambiais relativamente ortodoxas postas em prática na Nova Zelândia e na Austrália desde meados dos anos 1980 inviabilizaram a manipulação dessas variáveis em consonância com uma política industrial de apoio às exportações ${ }^{14}$.

De outro lado - e consequentemente -, a hipótese da eficiência produtiva das cadeias revelou-se ainda mais consistente do que nós mesmos poderíamos esperar. Isso no sentido de que a eficiência das cadeias leite/carne bovina e lã/carne ovina não pode prescindir do aproveitamento, ao limite, do potencial de sinergia das distintas "frações das mesmas". Expliquemo-nos.

\section{Um modelo de integração pecuária: as bovinoculturas de leite e carne}

Certamente, não terá passado despercebido o fato de usualmente nos referirmos a "a" (no singular) cadeia produtiva de "carne/leite bovina". Isso porque essa caracterização é rigorosamente não-convencional. Afinal, no Brasil, e na maior parte do mundo, as cadeias de laticínios e de carne/derivados são cadeias independentes, com integração que varia entre "pontual" e "nula". Em que sentido, pois, nos referimos a "uma única" cadeia de derivados bovinos? No sentido de que

\footnotetext{
${ }^{14}$ A esse respeito, vejam-se os trabalhos de Gould (2008) e Stilwell (2000).
} 
não pode haver eficiência "leiteira" se não forem exploradas suas conexões necessárias com a produção de carne.

Imaginemos uma economia pecuária leiteira de eficiência virtualmente perfeita $^{15}$. Nessa economia, o plantel de vacas ordenhadas gira em torno de quatro milhões, e esse estoque é bastante estável, pois não há fronteira agrícola aberta, nem espaço para ampliação da produtividade dentro do horizonte tecnológico atual. Esse rebanho leiteiro tem uma vida útil de 5 anos.

Para simplificação do cálculo, imaginemos, inicialmente, que todas as vacas são inseminadas, têm gestação bem sucedida ${ }^{16}$ e a mortalidade dos bezerros (excetuado o abate de vitelos) é zero ${ }^{17}$. Nesse caso, um plantel de quatro milhões de vacas gera outros quatro milhões de bezerros a cada ano. Em cinco anos - tempo médio de vida útil das vacas -, 20 milhões de bezerros são gerados. Deste total, quatro milhões de vacas são destinadas a repor o descarte do rebanho ordenhado. De sorte que restam dez milhões de bezerros machos (supondo que o nascimento de machos e fêmeas seja 50-50) e seis milhões de bezerros fêmeas, que são subprodutos da pecuária leiteira não incorporáveis a essa atividade. Se somarmos a esse plantel os quatro milhões de vacas ordenhadas descartadas ao fim do período útil, teremos 20 milhões de carcaças não incorporáveis à atividade leiteira. Tomando os valores anuais por referência, temos o seguinte quadro:

${ }^{15}$ Desnecessário dizer que a Nova Zelândia é a base empírica da construção ideal que se segue. As hipóteses simplificadoras adotadas aqui visam tão somente facilitar a compreensão do argumento global. Elas serão relaxadas mais adiante.

${ }^{16}$ Apesar de exigente, essa hipótese é mais realista do que se poderia esperar. Na Nova Zelândia, a inseminação artificial é amplamente disseminada, mas os estabelecimentos veterinários normalmente contam com alguns touros, que são alocados na cobertura das vacas cuja inseminação não foi bem sucedida. No caso dos distintos padrões de cruzamento mostrarem-se infrutíferos, a matriz é descartada, o que, usualmente, ocorre já no primeira manifestação da dificuldade reprodutiva.

17 Igualmente, essa é uma hipótese exigente mas mais realista do que se poderia pretender. $O$ padrão de manejo neozelandês conduz a uma mortalidade de bezerros que é discretamente superior à mortalidade infantil humana. 


\begin{tabular}{|l|r|}
\hline Rebanho & Cabeças (1000) \\
\hline Plantel de vacas de leite & 4.000 \\
\hline Bezerros nascidos por ano & 4.000 \\
\hline Reposição anual do plantel leite & 800 \\
\hline Descarte anual plantel leite & 800 \\
\hline Excedente total de gado para corte & 4.000 \\
\hline
\end{tabular}

Quadro 1A: Oferta anual de carcaças para corte do plantel leiteiro

Fonte: Cálculos do autor com base em dados de pesquisa

Em uma economia ineficiente, o descarte é sobra, lixo, "worthless", de forma que um milhão de vacas leiteiras podem gerar 1 milhão de carcaças "worthless" por ano. Ora, não há como deixar de se perguntar quão "worthless" pode ser um rebanho de um milhão de cabeças de gado bovino geradas como "subproduto" de uma atividade cujos custos se pagam apenas com o leite, seu produto principal.

Do nosso ponto de vista, uma economia leiteira eficiente não poderia deixar de dar destinação econômica eficiente para esse subproduto. Mais: nossa hipótese era a de que o volume e o baixo custo de um tal "subproduto" deveria impactar sobre a bovinocultura de corte, levando a algum tipo de integração (e, no limite, unificação) das cadeias de leite e carne. Temos a satisfação de comunicar que essa segunda hipótese confirmou-se integralmente em nossa pesquisa de campo na Nova Zelândia. A adequada compreensão dessa hipótese e de sua comprovação depende do entendimento dos processos de produção e de administração de custos nas bovinoculturas de corte e leite e dos limites (e possibilidades) de integração das duas cadeias.

Como é amplamente sabido, as raças bovinas que apresentam as melhores performances na produção de leite (Jersey e Holandesa), não são as melhores raças para a produção de carne. As raças cujos animais ganham volume de peso rapidamente e cuja carne apresenta características apreciadas no mercado pelo teor de gordura e maciez são outras (Angus, Hereford, etc.). Trata-se de um problema que tem sido resolvido, tradicionalmente, pela completa autonomia das duas cadeias.

A insuficiência dessa solução tradicional foi apontada acima: uma vez que para a produção de leite só as fêmeas (para além de um pequeno número de touros) 
são relevantes, e dado que a vida útil desses animais gira entre 5 e 6 anos, parcela não desprezível dos bezerros (condição sine qua non da produção de leite) assume a forma de um descarte de pouco ou nenhum valor, independentemente dessa mesma produção envolver custos. De outro lado, para a produção de carne, os machos - que ganham peso com maior velocidade e atingem um peso mais elevado - são mais valiosos. No entanto, para a produção de machos de corte, é preciso manter um plantel não desprezível (em torno de 30 por cento do total) de fêmeas (matrizes), que disputam espaço com os novilhos para abate e implicam custos relativamente elevados (alimentares e veterinários), a despeito de serem descartadas (ao fim de 5 ou 6 anos de vida útil como matrizes) a um valor bastante inferior ao obtido pelo novilho jovem. É fácil perceber que, se houvesse espaço para integração das duas cadeias, o excedente de machos da produção leiteira poderia ser absorvido pelo segmento de corte, que abriria mão de sustentar um número elevado de matrizes.

Para que se entenda o argumento, voltemos à nossa "economia leiteira ideal". Como vimos acima, um plantel de 4 milhões de vacas leiteiras deve produzir um número similar de bezerros por ano, mas só necessitam de algo em torno de 800 mil fêmeas como reposição das matrizes que perdem fertilidade e capacidade de geração de leite a cada ano. Nesse caso, em torno de 3,2 milhões de bezerros e 800 mil matrizes de descarte são postas a parte, a cada ano, com pouca ou nenhuma agregação de valor para os ambos. Imaginemos, agora, que uma parcela das matrizes leiteiras recebesse inseminação de touros de raças de corte ${ }^{18}$. Imaginemos, ainda, que o resultado do cruzamento fosse um animal com uma capacidade "razoável" (voltaremos a este ponto logo adiante) para ganhar peso e produzir uma

\footnotetext{
${ }^{18}$ Vale notar que nem todas as raças podem ser cruzadas em função das características anatômicas diferenciadas. As vacas Jersey apresentam uma estrutura demasiado pequena para serem cruzadas eficientemente com touros Hereford ou Angus. Mas o mesmo já não é verdade para a raça Holandesa, que apresenta uma carcaça maior e compatível com a das raças tipo carne. $A$ cruza Holandesa-Hereford (e, secundariamente, Holandesa-Angus) é a cruza predominante na Nova Zelândia hoje. Vale notar que a crescente integração entre as pecuárias de corte e leite no referido país vem impactando sobre o perfil do leite e mudando o plantel dominante. Até poucos anos atrás a raça dominante no rebanho leiteiro era o "kiwi cross" (uma mistura de Jersey com Holandês), que proporciona um volume de leite similar à holandesa com um conteúdo de sólido próximo ao proporcionado pela Jersey. Hoje, a raça holandesa volta a ganhar proeminência em função da crescente relevância do "descarte" de bezerros no fluxo de caixa dos ambos.
} 
carne de qualidade e aceitação no mercado, mas que as fêmeas deste cruzamento não apresentassem uma elevada produtividade como leiteiras. Neste caso, apenas uma parcela das matrizes leiteiras poderiam ser cruzadas com touros de "raças para corte". Mais exatamente, numa situação ideal, dos 4 milhões de bezerros gerados por ano, 2,4 milhões seriam "cruza leite/carne" e 1,6 milhão seriam puro leite (como forma de garantir 800 mil novas matrizes leiteiras de reposição, na expectativa 50/50 de nascimento de fêmeas e machos). Detalhamos este resultado no Quadro 2A:

\begin{tabular}{|c|r|r|r|}
\hline Animais redundantes & \multicolumn{1}{|c|}{ Total } & $\begin{array}{c}\text { Cruza } \\
\text { Leite/Carne }\end{array}$ & Raça Leite \\
\hline Bezerros machos & 2.000 & 1.200 & 800 \\
\hline Bezerros fêmeas & 1.200 & 1.200 & - \\
\hline Matrizes descartadas (7 anos) & 800 & - & 800 \\
\hline Total & 4.000 & 2.400 & 1.600 \\
\hline
\end{tabular}

Quadro 2A: Excedente Animal da Pecuária de Leite "Integrada" por Raça e Idade Fonte: Cálculos do autor com base em dados de pesquisa

Ora, os 800 mil bezerros machos da raça leite devem ter o destino "tradicional": produção de carne de vitelo, sendo abatidos bastante jovens (entre 4 dias e 3 meses). As matrizes descartadas também têm 0 destino tradicional: mercados de baixa renda, tolerantes com a qualidade inferior da carne. Mas os 2,4 milhões de animais que resultam do cruzamento das raças de corte e leite têm um destino totalmente distinto.

De acordo com as informações obtidas junto a pecuaristas dedicados exclusivamente a recria e terminação desses animais na Nova Zelândia, o cruzamento de vacas holandesas com touros Angus ou Hereford gera um animal

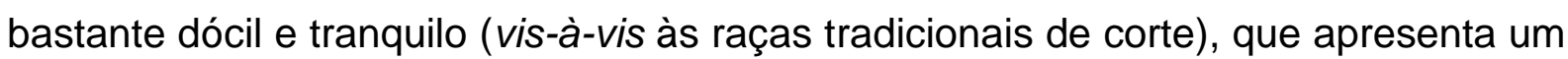
rápido e significativo ganho de peso, atingindo, em 18 a 24 meses, uma carcaça de volume e qualidade bastante similares aos animais "puro corte". Mas - e esta é a principal vantagem da cruza - esses animais são desenvolvidos em territórios (na realidade, em sistemas produtivos) destinados exclusivamente aos mesmos, sem qualquer "disputa" por terreno e alimento com matrizes e touros "de corte", que são tornados redundantes neste sistema. 
Buscando estabelecer uma comparação da rentabilidade prospectiva dos dois sistemas, montamos distintos cenários da pecuária de corte tradicional e comparamos a rentabilidade dos mesmos com o sistema integrado, na hipótese de que o mesmo funciona com a eficiência do sistema neozelandês. Por fim, calculamos o limite inferior de preço a que o animal "cruzado" (vis-à-vis o animal "puro corte") poderia atingir para que o sistema integrado garantisse a mesma rentabilidade do sistema tradicional. A conclusão a que chegamos - e que poderá ser averiguada na sequência - é que, o sistema integrado só deixa de ser mais rentável que o sistema tradicional se o preço do animal "cruzado" for inferior a 50 por cento do preço do animal "puro corte". Os quatro cenários considerados para a pecuária de corte tradicional foram caracterizados como "ruim", "razoável", "bom" e "excelente" e estão expostos no Quadro 3A:

\begin{tabular}{|l|r|r|r|r|}
\hline \multicolumn{1}{|c|}{ Cenários } & \multicolumn{1}{c|}{ Ruim } & Razoável & \multicolumn{1}{c|}{ Bom } & Excelente \\
\hline Mortalidade Matrizes & $10 \%$ & $10 \%$ & $5 \%$ & $2 \%$ \\
\hline Mortalidade Demais & $10 \%$ & $5 \%$ & $3 \%$ & $1 \%$ \\
\hline Taxa de Fertilidade & $50 \%$ & $70 \%$ & $90 \%$ & $99 \%$ \\
\hline Relação touros / matrizes & $5,0 \%$ & $5,0 \%$ & $2,5 \%$ & $1,7 \%$ \\
\hline
\end{tabular}

Quadro 3A:Taxas de mortalidade e fertilidade do gado de corte em quatro cenários Fonte: Cálculos do autor com base em dados de pesquisa

Buscando, ainda, contribuir para o cálculo e comparação de rentabilidade da pecuária de corte tradicional em cada um destes cenários e da pecuária de corte em condições de integração à pecuária leiteira, montamos um quadro com algumas hipóteses acerca do valor absoluto e relativo dos distintos ativos que compõem o plantel e a terra. Essas hipóteses são essencialmente especulativas e podem ser modificadas por quem quiser testar os resultados com valores alternativos ${ }^{19}$. Tomamos, como unidade de conta, o preço do novilho macho de 2 anos (que vale

${ }^{19}$ Para tanto, disponiblizamos o arquivo intitulado "Modelos Pecuários Leite e Corte.xlsx". Na primeira planilha (intitulada "Cenários e Preços") estão disponibilizados os sistemas de parâmetros utilizados. No caso dos parâmetros que compõem os distintos cenários, disponibilizamos alternativas que podem ser lançadas nas células pertinentes da segunda planilha (intitulada "Sistema"). Para o caso dos preços relativos, não disponibilizamos alternativas, mas as mesmas podem ser montadas pelos eventuais interessados e lançadas nas células pertinentes da segunda planilha com vistas a avaliar os resultados outras modelagens para as relações de intercâmbio. 
"1"). Todos os demais ativos (desde novilhos de 1 ano, até o hectare de terra, passando por touros e matrizes de 8 anos) são avaliados em relação a essa unidade. Reproduzimos, no Quadro 4A, abaixo, nossas hipóteses de preços relativos.

\begin{tabular}{|c|c|}
\hline \multicolumn{2}{|c|}{ Preço dos A tivos } \\
\hline Novilho de 2 anos & 1,00 \\
\hline Novilho de 1 ano & 0,40 \\
\hline Novilha de 2 anos & 0,80 \\
\hline Novilha de 1 ano & 0,32 \\
\hline M atriz de 8 anos & 0,50 \\
\hline M atriz (média) & 0,65 \\
\hline Touro & 6,00 \\
\hline Hectare & 5,00 \\
\hline
\end{tabular}

Quadro 4A: Preços relativos dos ativos na pecuária de corte Fonte: Cálculos do autor com base em dados de pesquisa

Por fim, vale observar que, ao modelarmos o sistema tradicional, consideramos que um único produtor é responsável pela cria, recria e terminação do gado. Essa hipótese se sustenta na medida em que estamos procurando modelar um sistema de produção (o tradicional) que envolve, necessariamente, estas três fases, independentemente delas poderem ser objeto de divisão de trabalho e especialização por parte de distintos agentes produtivos. Como se trata de um modelo com fins heurísticos, tomamos um estabelecimento "típico ideal", com 600 hectares, operado integralmente a pasto e que comporta 1200 reses. No caso do sistema tradicional, uma parte do rebanho é comporta por matrizes e touros, enquanto no sistema integrado todo o plantel é de novilhos e novilhas em recria e terminação para o abate. Os quadros comparativos da Estrutura e Produtividade Física (Quadro 13) e da Produtividade Econômica (Quadro 14) encontram-se no Anexo Estatístico.

O primeiro a salientar no que tange à produtividade física nos dois sistemas é que esta cresce de forma espetacular no sistema integrado quando comparado a qualquer cenário do sistema tradicional. A melhor relação abate/plantel do sistema tradicional é apresentado no cenário "excelente" (caracterizado por 99 por cento de fertilidade das matrizes e baixas taxas de mortalidade do plantel), e não chega a 
28,68 por cento, enquanto a relação entre novilhos em engorde e plantel total não chega a 50 por cento. No sistema integrado, o abate anual é de 49,75 por cento ao ano, e a totalidade do rebanho é composta de novilhos em processo de maturação para o abate.

No plano propriamente econômico - Quadro 14 do Anexo Estatístico introduzimos algumas hipóteses acerca dos preços relativos da animália e da terra com vistas a avaliar o faturamento sobre o patrimônio da firma "típico ideal" em distintos sistemas e cenários. Vale observar que não fizemos qualquer tentativa de determinação de despesas e custos monetários (veterinários, alimentares, mão deobra, administrativos, etc.). Se o fizéssemos, os resultados certamente se alterariam. Mas essa alteração se daria no sentido de amplificar as diferenças entre o sistema integrado leite/corte e o sistema tradicional. Afinal, os dispêndios veterinários e de mão de obra com a manutenção e atenção às matrizes em processo reprodutivo e novilhos de poucos dias tendem a ser superiores aos dispêndios com animais jovens. Além disso, as diferenças na relação faturamento/patrimônio nos distintos cenários do sistema tradicional - que já são notavelmente pequenas: a relação entre valor do abate e valor do patrimônio flutua de um mínimo de 5,25 por cento no cenário "ruim" até um máximo de 8,07 por cento no cenário "excelente" - seriam ainda mais deprimidas. Afinal, não é possível sair de um quadro de mortalidade de matrizes e novilhos em torno de 10 por cento ao ano para um quadro de mortalidade entre 2 por cento e 1 por cento sem incorrer em novos e expressivos custos de manutenção do plantel. Estes custos extras, com certeza, aproximariam os rendimentos de padrões técnicos e de gestão muito distintos ${ }^{20}$.

Mas se a relação entre o valor do gado abatido e o patrimônio se altera relativamente pouco com a adoção de padrões de manejo mais sofisticados e custosos (veja-se a última coluna do Quadro 14, no Anexo Estatístico), ele dá um

20 Acreditamos que a (já notável, mesmo quando abstraídos os diferenciais de custos diretos) proximidade dos indicadores de rendimento econômico, a despeito da enorme diferença dos padrões técnicos de gestão, possa explicar, pelo menos em parte, as resistências de parcela não desprezível dos pecuaristas em adotar inovações gerenciais que, sem sombra de dúvida, envolvem elevação de custos e riscos financeiros crescentes. 
enorme salto quando transitamos do sistema tradicional para o sistema integrado. $\mathrm{Na}$ hipótese (irrealista) de que os novilhos "cruzados" obtivessem o mesmo preço dos novilhos "puro corte", o crescimento do faturamento seria de 81,27 por cento, passando de 8,07 por cento do patrimônio para 14,63 por cento do patrimônio. Mas se esse resultado pode ser criticado por meramente especulativo, o mesmo não pode ser dito do seu desdobramento necessário: o preço do novilho "cruzado" teria de ser inferior a 50 por cento ${ }^{21}$ do novilho "puro corte" para que o faturamento sobre o patrimônio fosse inferior àquele obtido dentro de padrões tradicionais.

Vale observar que a principal determinação do extraordinário crescimento da relação faturamento / patrimônio é a eliminação do plantel de matrizes e touros, que se desdobra na elevação da rotação do capital, expresso no índice de 49,75 por cento de animais abatidos ao ano. Contudo, esse resultado é reforçado pela alteração da relação entre machos e fêmeas no plantel. Na medida em que a pecuária leiteira retém parte das fêmeas para sua atividade, o plantel de corte no modelo integrado apresenta uma relação macho/fêmea de 166,66 por cento (vide Quadro 3A e o Quadro 13 do Anexo Estatístico).

Esse desdobramento secundário da integração das pecuárias bovinas de corte e leite transparece na estrutura do plantel bovino da Nova Zelândia, país que serve de referência para o modelo desenvolvido acima. Essa estrutura é apresentada nos Quadros 15 e 16 do Anexo Estatístico, baseados no Censo Agropecuário realizado em 2007 no referido país. No Quadro 15, apresentamos algumas das características mais gerais da agropecuária neozelandesa, com ênfase no número de estabelecimentos (147 mil, dos quais 121 mil são especializados em atividades pecuárias), e na área média dos mesmos (em torno de 232 ha), que é diferenciada para cada uma das principais atividades agropecuárias (141,42 ha para a bovinocultura de corte).

No Quadro 16, detalhamos a estrutura das atividades pecuárias, diferenciando o plantel bovino destinado ao corte e à produção leiteira, bem como a distribuição deste plantel entre machos e fêmeas. Vale notar que, tanto no Quadro 15 quanto no

\footnotetext{
${ }^{21}$ Mais exatamente, de $49,45 \%$.
} 
Quadro 16, optamos por classificar os estabelecimentos (e o respectivo plantel) que operam simultaneamente com criação de ovinos e bovinos como estabelecimentos "ovinocultores". Com essa opção, buscamos diferenciar os estabelecimentos em que a bovinocultura de corte se distancia da ovinocultura em função da associação com a pecuária de leite - típicos da ilha norte - e os estabelecimentos em que a pecuária de corte ainda se estrutura sobre o sistema tradicional - típico da ilha sul, onde a ovinocultura é a atividade pecuária mais importante. Essa diferenciação fica patente na coluna "Relação Macho/Fêmea" do Quadro 16, cujas células encontram-se achuriadas. Como se pode observar no mesmo, a relação entre machos e fêmeas bovinos no plantel voltado ao corte é de 121 por cento para o conjunto da Nova Zelândia; mas chega a ser de 182 por cento no plantel de corte dos estabelecimentos dedicados exclusivamente a esta atividade. Evidentemente, esse resultado só pode ser obtido na medida em que a associação com a pecuária leiteira determina a supressão do estoque de matrizes por parte da bovinocultura voltada à produção de carne.

Infelizmente, nosso Censo Agropecuário não diferencia as atividades de leite e corte, tratando o plantel bovino como uma unidade. Não obstante, tendo em vista que a atividade de corte é muito mais expressiva do que a atividade leiteira na maior parte das Unidades da Federação, a relação entre machos e fêmeas do plantel bovino como um todo é uma proxy razoável da relação padrão na bovinocultura de corte tradicional. Essa relação é apresentada na última coluna do Quadro 17 Composição do efetivo de bovinos nos estabelecimentos com mais de 50 cabeças em 31.12.2006 por UF - do Anexo Estatístico. Como se pode observar no mesmo, ao contrário do que ocorre na Nova Zelândia, o número de machos é significativamente inferior ao número de fêmeas em todos os Estados da Federação, sendo que essa relação é de 72,2 por cento para o Brasil e de 62,08 por cento para o Rio Grande do Sul22.

${ }^{22}$ É de se notar que esta relação é significativamente mais elevada do que a que se extrai do modelo de pecuária de corte tradicional desenvolvido por nós, em qualquer dos quatro cenários propostos. De acordo com nosso modelo, a relação macho/fêmea deveria variar de um mínimo de 36 por cento no cenário de menor produtividade até um máximo de 50 por cento no melhor cenário. A diferença entre nossa modelagem e os dados empíricos se explica pelo fato de termos introduzidos 


\section{Considerações Finais}

O objetivo inicial deste trabalho era o de investigar como os dois mais importantes países da Oceania atingiram patamares extraordinariamente elevados de desenvolvimento a despeito de serem economias de origem colonial que se estruturaram como exportadores de alimentos e matérias-primas para a Europa, Estados Unidos e os países desenvolvidos da Ásia. A despeito de termos clareza do grande impacto da distribuição da renda (que amplifica o multiplicador e potencializa o acelerador da economia) e dos padrões cívicos diferenciados desses dois países (que se desdobram em depressão dos custos de transação e a eficiência da ação econômica do Estado), havia uma questão que nos intrigava de forma particular: em sistemas econômicos do tipo do australiano e do neozelandês, dada a distribuição da renda e o multiplicador, a taxa de crescimento da economia torna-se função da taxa de crescimento das exportações. Como esses dois países conseguiram emprestar sustentabilidade de longo prazo ao crescimento de suas exportações de matérias-primas? E, em particular: como esses dois países conseguiram superar os entraves alfandegários, fitossanitários e burocráticos interpostos pelas principais economias desenvolvidas do mundo no bojo de suas políticas de proteção e subsídio à produção agropecuária interna?

Imediatamente, duas hipóteses se colocavam para a extraordinária competitividade "oceânica": câmbio cronicamente desvalorizado ou elevada produtividade sistêmica no interior das principais cadeias exportadoras ${ }^{23}$.

duas simplificações em nossa modelagem: 1) a abstração da existência de animais de trabalho (bois de carga) nos estabelecimentos pecuários; e 2) a pressuposição de que todo o rebanho destinado a corte é abatido com 2 anos de idade. Evidentemente, estas hipóteses simplificadoras alavancam artificiosamente a relação faturamento/patrimônio. Os resultados seriam ainda piores do que os modelados por nós se abríssemos mão dessas simplificações. Não obstante, mantivemos as hipóteses restritivas na medida em que percebemos a introdução de hipóteses mais realistas complexificaria sobremaneira o modelo sem gerar ganhos expressivos em termos de compreensão das diferenças fundamentais entre os sistemas tradicional e integrado à pecuária leiteira.

${ }^{23}$ A hipótese da conquista de mercados externos crescentes a partir de subsídios governamentais nunca nos pareceu subsistente. Afinal - como procuramos demonstrar na seção terceira deste trabalho - o lucro bruto (vale dizer: a totalidade do excedente social antes dos impostos) de um sistema econômico típico ideal assentado na exportação de commodities corresponde ao valor das exportações. Antes de ser um beneficiário da exação pública, o setor exportador em um país sem D1 é a fonte primária dessa exação. As políticas brasileiras para o café são exemplares, neste 
Entendemos que a adequada avaliação da pertinência ou impertinência dessas hipóteses pressupunha o conhecimento in loco da realidade econômica dos dois países. O que se resolveu em nossa visita de trabalho aos mesmos entre os dias 13 e 23 de dezembro de 2010.

Tal como já o dissemos, a hipótese de que a competitividade dos países da Oceania se estruturasse sobre o câmbio se mostrou totalmente insubsistente. $\mathrm{Na}$ realidade, tanto a Austrália quanto a Nova Zelândia adotam políticas monetáriocambiais muito similares às que o Brasil adotou desde o Plano Real, o que se resolve em certa tendência à sobrevalorização monetária, que tensiona negativamente as exportações.

De outro lado, a hipótese de que as cadeias agropecuárias dos dois países apresentam níveis extraordinários de produtividade mostrou-se inteiramente consistente. Mais: averiguamos, in loco, que essa produtividade extraordinariamente elevada é indissociável da introdução de inovações no plano da integração das cadeias, aproveitamento econômico de subprodutos e agregação de valor aos mesmos. Esse padrão de integração e agregação de valor perpassa as mais distintas cadeias agropecuárias dos dois países, envolvendo grãos, frutas e bebidas e as mais distintas pecuárias, com ênfase nas ovinoculturas de lã/corte e bovinoculturas leite/carne. Dada a impossibilidade de tratar com rigor e determinação de todos os sistemas, ativemo-nos àquele processo de integração que nos parece ser o mais original e que apresenta maior potencial de replicabilidade para o desenvolvimento da agropecuária gaúcha: a integração neozelandesa das bovinocultura de carne e leite ${ }^{24}$.

A importância desse sistema encontra-se nos seus desdobramentos em termos de alavancagem da rentabilidade e competitividade nas duas cadeias. As

sentido: nada impede - pelo contrário, exige-se - que, em períodos de crise da demanda externa o Estado alavanque a lucratividade do setor estruturador da economia; mas este setor não pode se sustentar, no longo prazo, a partir de subsídios. Pelo contrário: tal como o fizemos no longo período de diferenciação e confisco cambial sobre o café, o "Departamento Exportador" tende a se tornar (mesmo que por via indiretas) a fonte privilegiada de exação fiscal.

${ }^{24}$ É importante que se entenda, contudo, que este sistema de integração é apenas um exemplo de exploração de sinergias e agregação de valor a subprodutos que tem um caráter bastante geral. Na realidade, trata-se da aplicação, às cadeias do leite e da carne bovina, da teoria da inovação de Penrose, exposta em seu clássico sobre o crescimento da firma (PENROSE, 1962). 
consequências na bovinocultura de corte foram objeto de detalhamento na seção anterior deste trabalho e não cabe retoma-las aqui. Mas cabe explorar rapidamente as consequências para a produção leiteira.

O desdobramento primeiro para a bovinocultura de leite do processo de integração supra referido é a emergência de uma nova e importante fonte de renda para o produtor, associado à venda de bezerros oriundos da cruza de vacas de leite com touros "de corte". Uma vez que a atividade leiteira é, tipicamente, uma atividade da agricultura familiar, essa elevação da renda resolve-se, imediatamente, em melhoria da distribuição da renda e elevação do consumo e da demanda nos "territórios leiteiros", com desdobramentos positivos para o desenvolvimento regional. Em longo prazo, contudo, as consequências são distintas. A elevação da renda na atividade leiteira estimula o ingresso de novos produtores no mercado, com a subsequente elevação da oferta e depressão de preços. Trata-se de um desdobramento que não pode deixar de ser "mal visto" pelos produtores diretos, mas que tem consequências positivas para o desenvolvimento territorial global. Isso ocorre na medida em que o principal entrave à ampliação da oferta das atividades mercantis em geral (e dos segmentos de livre ingresso, em particular) é a limitação de mercado. A condição necessária para o enfrentamento dessa limitação é a operação com níveis de produtividade superiores (e preços inferiores) aos da concorrência atual e potencial. Isso significa dizer que a depressão de preços do produto principal (leite fluído), associada ao ingresso de novos produtores em busca da rentabilidade extraordinária da pecuária leiteira integrada ao corte, deve redundar na consolidação dos territórios inovadores como fornecedores em grande escala de um mercado que - a despeito de crescente no Brasil e no mundo - apresenta um potencial de expansão inferior ao potencial de expansão da oferta. O crescimento da escala em termos regionais deve redundar na consolidação competitiva dos segmentos industrial e comercial da cadeia leiteira, com novos desdobramentos positivos para a conquista de mercados externos. Esse é, em síntese, o círculo virtuoso que caracteriza a dairy chain neozelandesa. 
De outro lado - mas ainda da perspectiva da economia regional -, a ampliação do mercado para a produção leiteira regional resolve-se por meio da ampliação do rebanho leiteiro e, por consequência, da elevação da oferta de animais "cruzados" para a pecuária de corte. Isso deve resultar na depressão sistêmica da pecuária tradicional, com a consequente depressão do número de matrizes e touros e a elevação do desfrute e da rentabilidade nesse segmento da bovinocultura. O mais importante é que a vantagem competitiva da bovinocultura de corte que alcança se integrar à bovinocultura do leite não é replicável para os demais territórios não especializados em leite. Isso envolve a conquista de uma competitividade absolutamente particular (porquanto indissociável do território) que, na nossa avaliação preliminar, parece ser suficientemente elevada para compensar as vantagens competitivas de territórios que contam com fronteiras agrícolas em expansão (como o Centro-Oeste e no Norte do país) e, por consequências, apresentam custos de imobilização (e de oportunidade) significativamente menores.

Por fim, a integração das pecuárias de corte e leite no Rio Grande do Sul pode cumprir uma função político-cultural não desprezível: a articulação e solidarização das "duas Metades" do Estado: a Metade Norte - que continua sendo a principal produtora de leite, malgrado a significativa e alvissareira expansão da atividade na porção meridional - e a Metade Sul - que continua sendo a principal produtora de gado de corte. Trata-se de um desdobramento cuja importância não pode ser subestimada em um Estado que ainda preserva marcas de uma longa e dolorosa história de conflitos e estranhamentos entre suas porções Norte e Sul.

\section{Referências}

GOULD, B. Rescuing The New Zealand Economy: What Went Wrong and How We Can Fix It. Nelson: Craig Potton Publishing, 2008.

LAZZARI, M. A Economia Gaúcha na visão das Contas Regionais - 1981/2009. 2010. In: Três Décadas de Economia Gaúcha: o movimento da produção. Vol. II. Porto Alegre: FEE. Disponível em: <http://www.fee.rs.gov.br/3-decadas/movimentoda-producao.php>. Acesso em: 10 abr. 2012. 
MATRIZ DE INSUMO PRODUTO DO RIO GRANDE DO SUL. Porto Alegre: Fundação de Economia e Estatística Siegfried Emanuel Heuser. Disponível em: $<$ http://www.fee.tche.br/sitefee/pt/content/estatisticas/pg_mip.php>. Acesso em: 10 mar. 2012.

PAIVA, C. A. Capital Social, Comunidade, Democracia e o Planejamento do Desenvolvimento no Rio Grande do Capital Social, Comunidade, Democracia e o Planejamento do Desenvolvimento no Rio Grande do Sul. In: WITTMANN, M.; PAIVA, C. A. Demanda Efetiva, exportações e desenvolvimento regional. In: Anais do IX Encontro Nacional de Economia Política. Uberlândia: SEP-UFU, 2004a. CDRom

. Os determinantes do aprofundamento das desigualdades territoriais no Rio

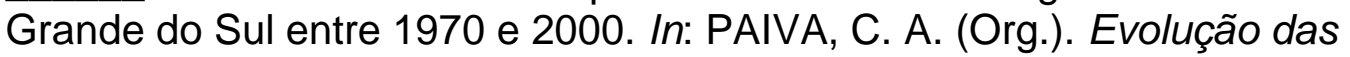
desigualdades territoriais do Rio Grande do Sul. Santa Cruz do Sul: Edunisc, 2008c.

. Modelo Macrodinâmico. 2008a. In: Territoriopaiva.com. Disponível em: $<$ http://territoriopaiva.com/blog1/aulas/curso-diplomacia/desenvolvimento-economiabrasileira>. Acesso em: 10 mar. 2012.

. Smith, Kalecki e North e os fundamentos de uma teoria geral do desenvolvimento de regiões periféricas em transição para o capitalismo. In: Anais do II Encontro de Economia Gaúcha. 2004b. Porto Alegre: FEE / PUC-RS. Disponível em: <http://www.fee.rs.gov.br/sitefee/pt/content/eeg/\#mesa11>. Acesso em: 10 mar. 2012.

. Valor, preços e distribuição: de Ricardo a Marx, de Marx a nós. Porto Alegre: Fundação de Economia e Estatística, 2008b. (Série Teses, n. 9). Disponível em: <http://www.fee.tche.br/sitefee/download/teses/teses_fee_09.pdf>. Acesso em: 10 mar. 2012.

PENROSE, E. Teoría del crecimiento de la empresa. Madri: Aguillar, 1962.

PORSSE, A. A. Matriz de Insumo-Produto do Rio Grande do Sul em 2003. 2007. Porto Alegre: FEE. Disponível em:

<http://www.fee.tche.br/sitefee/pt/content/estatisticas/pg_mip.php>. Acesso em: 4 abr. de 2012.

RAMOS, M. (Org.) Desenvolvimento Regional: Capital Social, Redes e Planejamento. Santa Cruz do Sul: Edunisc, 2004c.

STILWELL, F. Changing Track: A New political economic direction for Australia. New South Wales: Pluto Press, 2000. 


\section{ANEXO ESTATÍSTICO}

\section{Relatório de pesquisa: "Da Oceania ao Cone Sul, da Nova Zelândia ao Rio Grande"}

\begin{tabular}{|c|c|c|c|c|c|c|c|c|c|c|c|}
\hline Países & $\begin{array}{l}\text { Área em } \\
\mathrm{Km} 2(\mathrm{~A})\end{array}$ & $\begin{array}{c}\text { \% Área } \\
\text { Pastagens }\end{array}$ & $\begin{array}{c}\text { \% Área } \\
\text { Agriculura }\end{array}$ & \begin{tabular}{|l|} 
\% Área \\
Proteção
\end{tabular} & $\begin{array}{l}\text { População Total } \\
2010 \text { (A) }\end{array}$ & $\begin{array}{l}\text { Densidade } \\
\text { Demográfica }\end{array}$ & $\begin{array}{c}\text { Grau de } \\
\text { Urbanização }\end{array}$ & $\begin{array}{c}\text { Renda PC em } \\
\text { US\$ - } 2008 \text { (B) }\end{array}$ & $\begin{array}{l}\% \text { Renda } \\
20 \% \text { mais } \\
\text { Pobres (c) }\end{array}$ & $\begin{array}{c}\text { Gini da } \\
\text { Renda - } \\
\text { Med 1995- } \\
2004 \text { (D) }\end{array}$ & \begin{tabular}{|c|} 
Ranking \\
Concentração \\
de Renda de \\
137 países \\
(F) \\
\end{tabular} \\
\hline Austrália & 713.364 & $49,58 \%$ & $5,80 \%$ & $16,71 \%$ & 21.511.888 & 2,789 & $88,93 \%$ & 40.350 & $5,90 \%$ & 43,38 & 112 \\
\hline Nova Zelândia & 270.986 & $42,41 \%$ & $3,48 \%$ & $20,53 \%$ & 4.303 .457 & 15,881 & $86,66 \%$ & 27.940 & $6,40 \%$ & 46,28 & 95 \\
\hline Brasil & 8.514 .876 & $23,29 \%$ & $7,86 \%$ & $28,92 \%$ & 195.423.252 & 22,951 & $86,12 \%$ & 7.350 & $3,00 \%$ & 68,69 & 7 \\
\hline
\end{tabular}

Fontes (indicadas pelas letras nas células do cabeçalho)
A) IBGE países http://www.ibge.gov.br/paisesat/
B) Banco Mundial http://data.un.org/Data.aspx?d=WDI\&f=Indicator Code:SI.DST.FRST.20
C) Banco Mundial http://data.un.org/Data.aspx?d=WDI\&f=Indicator Code:NY.GNP.PCAP.CD
D) Swidd - F. Solt http://www.siuc.edu/ fsolt/swiid/swiid.html
E) Territorio Paiva http://www.territoriopaiva.com/ctms/1/42/mundo

Quadro 1: Indicadores socioeconômicos e geográficos dos cinco países selecionados 


\begin{tabular}{|c|c|c|c|c|c|c|c|c|c|}
\hline \multirow{2}{*}{$\begin{array}{l}\text { New Zealand - } \\
\text { Balance of Trade }\end{array}$} & \multicolumn{4}{|c|}{ EXPORTS (FOB) } & \multicolumn{4}{|c|}{ IMPORTS (CIF) } & \multirow[b]{2}{*}{ Balance } \\
\hline & $\begin{array}{c}\text { Value } \\
2009 \\
\end{array}$ & $\begin{array}{c}\text { Var } \\
05 / 09\end{array}$ & $\begin{array}{c}2009 \\
\text { share }\end{array}$ & \begin{tabular}{|c|}
$\begin{array}{c}\text { Cumulated } \\
\text { share }\end{array}$ \\
\end{tabular} & $\begin{array}{c}\text { Value } \\
2009 \\
\end{array}$ & Var 05/09 & $\begin{array}{c}2009 \\
\text { share }\end{array}$ & $\begin{array}{c}\text { Cumulated } \\
\text { share }\end{array}$ & \\
\hline 1) Food & $12.962,00$ & $4,9 \%$ & $52,0 \%$ & $52,0 \%$ & $2.573,40$ & $8,1 \%$ & $10,1 \%$ & $10,1 \%$ & $10.388,60$ \\
\hline 2) Crude Material & $2.653,00$ & $1,8 \%$ & $10,6 \%$ & $62,6 \%$ & 572,20 & $-2,6 \%$ & $2,2 \%$ & $12,3 \%$ & $2.080,80$ \\
\hline 3) Fuel and oils & $1.189,90$ & $37,4 \%$ & $4,8 \%$ & $67,4 \%$ & $3.695,10$ & $3,9 \%$ & $14,5 \%$ & $26,8 \%$ & $-2.505,20$ \\
\hline 4) Chemical & $1.310,80$ & $2,8 \%$ & $5,3 \%$ & $72,7 \%$ & $2.995,10$ & $0,4 \%$ & $11,7 \%$ & $38,5 \%$ & $-1.684,30$ \\
\hline 5) Manufactured Goods & $2.224,90$ & $-4,1 \%$ & $8,9 \%$ & $81,6 \%$ & $3.025,70$ & $-2,8 \%$ & $11,8 \%$ & $50,3 \%$ & $-800,80$ \\
\hline 6) Machinery and Transport & $2.238,90$ & $-2,7 \%$ & $9,0 \%$ & $90,6 \%$ & $8.739,80$ & $-4,9 \%$ & $34,2 \%$ & $84,5 \%$ & $-6.500,90$ \\
\hline 7) Miscellaneous & $1.102,60$ & $2,0 \%$ & $4,4 \%$ & $95,0 \%$ & $3.736,80$ & $2,5 \%$ & $14,6 \%$ & $99,1 \%$ & $-2.634,20$ \\
\hline 8) Others & $1.250,10$ & $8,7 \%$ & $5,0 \%$ & $100,0 \%$ & 207,00 & $10,5 \%$ & $0,8 \%$ & $100,0 \%$ & $1.043,10$ \\
\hline 9) Total & $24.932,10$ & $3,5 \%$ & $100 \%$ & - & $25.545,00$ & $-0,6 \%$ & $100 \%$ & - & $-612,90$ \\
\hline
\end{tabular}

Quadro 2: Balança comercial da Nova Zelândia em 2009 


\begin{tabular}{|c|r|r|r|r|r|r|r|r|r|}
\hline \multirow{2}{*}{$\begin{array}{c}\text { Australia } \\
\text { Balance of Trade }\end{array}$} & \multicolumn{4}{|c|}{ EXPORTS (FOB) } & \multicolumn{4}{|c|}{ IMPORTS (CIF) } \\
\cline { 2 - 10 } & Value 2009 & $\begin{array}{c}\text { Var } \\
05 / 09\end{array}$ & $\begin{array}{c}2009 \\
\text { share }\end{array}$ & $\begin{array}{c}\text { Cumulated } \\
\text { share }\end{array}$ & Value 2009 & $\begin{array}{c}\text { Var } \\
05 / 09\end{array}$ & $\begin{array}{c}2009 \\
\text { share }\end{array}$ & $\begin{array}{c}\text { Cumulated } \\
\text { share }\end{array}$ & Balance \\
\hline 1) Food & $18.948,40$ & $3,5 \%$ & $12,4 \%$ & $12,4 \%$ & $8.229,30$ & $12,2 \%$ & $5,2 \%$ & $5,2 \%$ & $10.719,10$ \\
\hline 2) Crude Material & $39.590,60$ & $15,4 \%$ & $25,8 \%$ & $38,2 \%$ & $2.036,60$ & $3,6 \%$ & $1,3 \%$ & $6,5 \%$ & $37.554,00$ \\
\hline 3) Fuel and oils & $45.187,20$ & $13,6 \%$ & $29,5 \%$ & $67,6 \%$ & $20.108,30$ & $11,1 \%$ & $12,7 \%$ & $19,2 \%$ & $25.078,90$ \\
\hline 4) Chemical & $6.308,00$ & $6,4 \%$ & $4,1 \%$ & $71,7 \%$ & $17.089,60$ & $6,0 \%$ & $10,8 \%$ & $30,0 \%$ & $-10.781,60$ \\
\hline 5) Manufactured Goods & $10.736,50$ & $2,2 \%$ & $7,0 \%$ & $78,7 \%$ & $17.189,00$ & $5,6 \%$ & $10,8 \%$ & $40,8 \%$ & $-6.452,50$ \\
\hline 6) Machinery and Transport & $9.335,90$ & $-1,8 \%$ & $6,1 \%$ & $84,8 \%$ & $60.662,40$ & $3,6 \%$ & $38,2 \%$ & $79,0 \%$ & $-51.326,50$ \\
\hline 7) Miscellaneous & $3.975,40$ & $4,1 \%$ & $2,6 \%$ & $87,4 \%$ & $21.662,10$ & $7,5 \%$ & $13,6 \%$ & $92,6 \%$ & $-17.686,70$ \\
\hline 8) Others & $19.318,80$ & $13,5 \%$ & $12,6 \%$ & $100,0 \%$ & $11.945,30$ & $47,4 \%$ & $7,5 \%$ & $100,1 \%$ & $7.373,50$ \\
\hline 9) Total & $153.400,80$ & $9,7 \%$ & $100,0 \%$ & - & $158.922,70$ & $7,5 \%$ & $100,0 \%$ & - & $-5.521,90$ \\
\hline
\end{tabular}

Source: UNO Comtrade, disp in: http://comtrade.un.org/pb/CountryPagesNew.aspx?y=2009 Value in million US\$

Quadro 3: Balança comercial da Austrália em 2009 


\begin{tabular}{|c|c|c|c|c|c|c|c|c|c|}
\hline \multirow[b]{2}{*}{ Brazil - Balance of Trade } & \multicolumn{4}{|c|}{ EXPORTS (FOB) } & \multicolumn{4}{|c|}{ IMPORTS } & \multirow[b]{2}{*}{ Balance } \\
\hline & Value 2009 & $\begin{array}{c}\text { Var } \\
05 / 09 \\
\end{array}$ & $\begin{array}{c}2009 \\
\text { share (\%) }\end{array}$ & $\begin{array}{c}\text { Cumulated } \\
\text { share }\end{array}$ & Value 2009 & \begin{tabular}{|c|} 
Var \\
$05 / 09$
\end{tabular} & $\begin{array}{c}2009 \\
\text { share }\end{array}$ & $\begin{array}{c}\text { Cumulated } \\
\text { share }\end{array}$ & \\
\hline 1) Food & $38.904,20$ & $13,4 \%$ & $25,4 \%$ & $25,4 \%$ & $6.064,70$ & $20,2 \%$ & $4,8 \%$ & $4,8 \%$ & $32.839,50$ \\
\hline 2) Crude Material & $35.271,70$ & $14,2 \%$ & $23,1 \%$ & $48,5 \%$ & $3.466,60$ & $7,1 \%$ & $2,7 \%$ & $7,5 \%$ & $31.805,10$ \\
\hline 3) Fuel and oils & $13.657,50$ & $17,8 \%$ & $8,9 \%$ & $57,4 \%$ & $18.864,10$ & $8,8 \%$ & $14,8 \%$ & $22,2 \%$ & $5.206,60$ \\
\hline 4) Chemical & $10.486,00$ & $9,5 \%$ & $6,9 \%$ & $64,3 \%$ & $25.250,30$ & $14,6 \%$ & $19,8 \%$ & $42,0 \%$ & $-14.764,30$ \\
\hline 5) Manufactured Goods & $19.745,80$ & $-2,4 \%$ & $12,9 \%$ & $77,2 \%$ & $14.102,50$ & $16,7 \%$ & $11,0 \%$ & $53,1 \%$ & $5.643,30$ \\
\hline 6) Machinery and Transport & $26.322,30$ & $-3,7 \%$ & $17,2 \%$ & $94,4 \%$ & $50.959,10$ & $16,3 \%$ & $39,9 \%$ & $93,0 \%$ & $-24.636,80$ \\
\hline 7) Miscellaneous & $4.407,20$ & $-2,6 \%$ & $2,9 \%$ & $97,3 \%$ & $8.938,90$ & $18,7 \%$ & $7,0 \%$ & $100,0 \%$ & $-\quad 4.531,70$ \\
\hline 8) Others & $4.200,20$ & $12,3 \%$ & $2,7 \%$ & $100,0 \%$ & 1,00 & $50,7 \%$ & $0,0 \%$ & $100,0 \%$ & $4.199,20$ \\
\hline Total & $152.994,70$ & $6,6 \%$ & $100,0 \%$ & & $127.647,30$ & $14,8 \%$ & $100,0 \%$ & & $25.347,40$ \\
\hline
\end{tabular}

Source: UNO Comtrade, disp in: http://comtrade.un.org/pb/CountryPagesNew.aspx?y=2009 Value in million US\$

Quadro 4: Balança comercial do Brasil em 2009 


\begin{tabular}{|c|r|r|r|r|r|r|r|r|r|}
\hline \multirow{2}{*}{$\begin{array}{c}\text { Argentina } \\
\text { Balance of Trade }\end{array}$} & \multicolumn{4}{|c|}{ EXPORTS (FOB } & \multicolumn{3}{|c|}{ IMPORTS } & \multirow{2}{*}{ Balance } \\
\cline { 2 - 10 } & Value 2008 & $\begin{array}{c}\text { Var } \\
04 / 08\end{array}$ & $\begin{array}{c}2008 \\
\text { share }\end{array}$ & $\begin{array}{c}\text { Cumulated } \\
\text { share }\end{array}$ & Value 2008 & $\begin{array}{c}\text { Var } \\
04 / 08\end{array}$ & $\begin{array}{c}2008 \\
\text { share }\end{array}$ & $\begin{array}{c}\text { Cumulated } \\
\text { share }\end{array}$ & \\
\hline 1) Food & $25.074,50$ & $21,2 \%$ & $35,8 \%$ & $35,8 \%$ & $1.177,0$ & $21,5 \%$ & $2,0 \%$ & $2,0 \%$ & $23.897,50$ \\
\hline 2) Crude Material & $13.617,60$ & $20,8 \%$ & $19,4 \%$ & $55,3 \%$ & $3.559,0$ & $35,6 \%$ & $6,2 \%$ & $8,2 \%$ & $10.058,60$ \\
\hline 3) Fuel and oils & $6.716,80$ & $5,0 \%$ & $9,6 \%$ & $64,9 \%$ & $4.132,8$ & $45,5 \%$ & $7,2 \%$ & $15,4 \%$ & $2.584,00$ \\
\hline 4) Chemical & $5.808,20$ & $18,9 \%$ & $8,3 \%$ & $73,1 \%$ & $10.406,6$ & $20,1 \%$ & $18,1 \%$ & $33,6 \%$ & $-4.598,40$ \\
\hline 5) Manufactured Goods & $5.877,80$ & $13,8 \%$ & $8,4 \%$ & $81,5 \%$ & $7.840,7$ & $24,7 \%$ & $13,7 \%$ & $47,2 \%$ & $-1.962,90$ \\
\hline 6) Machinery and Transport & $9.746,50$ & $33,0 \%$ & $13,9 \%$ & $95,5 \%$ & $26.255,5$ & $27,4 \%$ & $45,7 \%$ & $92,9 \%$ & $-16.509,00$ \\
\hline 7) Miscellaneous & $1.097,00$ & $11,0 \%$ & $1,6 \%$ & $97,0 \%$ & $3.746,4$ & $26,3 \%$ & $6,5 \%$ & $99,5 \%$ & $-2.649,40$ \\
\hline 8) Others & $2.082,20$ & $28,6 \%$ & $3,0 \%$ & $100,0 \%$ & 304,2 & $5,4 \%$ & $0,5 \%$ & $100,0 \%$ & $1.778,00$ \\
\hline Total & $70.020,50$ & $19,3 \%$ & $100,0 \%$ & & $57.422,1$ & $26,5 \%$ & $100,0 \%$ & & $12.598,40$ \\
\hline
\end{tabular}

Source: UNO Comtrade, disp in: http://comtrade.un.org/pb/CountryPagesNew.aspx?y=2009

Os dados para a Argentina foram disponibilizados apenas para 2008

Quadro 5: Balança comercial da Argentina em 2008 


\begin{tabular}{|c|c|c|c|c|c|c|c|c|c|}
\hline \multirow[b]{2}{*}{ Uruguay - Balance of Trade } & \multicolumn{4}{|c|}{ EXPORTS (FOB) } & \multicolumn{4}{|c|}{ IMPORTS } & \multirow[b]{2}{*}{ Balance } \\
\hline & Value 2009 & $\begin{array}{c}\text { Var } \\
2005 / 2009\end{array}$ & $\begin{array}{l}2009 \\
\text { share }\end{array}$ & $\begin{array}{c}\text { Cumulated } \\
\text { share }\end{array}$ & $\begin{array}{c}\text { Value } \\
2009\end{array}$ & $\begin{array}{c}\text { Var } \\
2005 / 2009\end{array}$ & $\begin{array}{l}2009 \\
\text { share }\end{array}$ & $\begin{array}{c}\text { Cumulated } \\
\text { share }\end{array}$ & \\
\hline 1) Food & $2.924,40$ & $14,5 \%$ & $54,3 \%$ & $54,3 \%$ & 626,10 & $21,8 \%$ & $9,1 \%$ & $9,1 \%$ & $2.298,30$ \\
\hline 2) Crude Material & $1.037,70$ & $21,5 \%$ & $19,3 \%$ & $73,6 \%$ & 243,70 & $7,4 \%$ & $3,5 \%$ & $12,6 \%$ & 794,00 \\
\hline 3) Fuel and oils & 73,50 & $-18,0 \%$ & $1,4 \%$ & $74,9 \%$ & $1.683,00$ & $15,6 \%$ & $24,4 \%$ & $37,0 \%$ & $-1.609,50$ \\
\hline 4) Chemical & 347,10 & $15,0 \%$ & $6,4 \%$ & $81,4 \%$ & $1.110,70$ & $10,2 \%$ & $16,1 \%$ & $53,1 \%$ & $-\quad 763,60$ \\
\hline 5) Manufactured Goods & 466,60 & $-1,3 \%$ & $8,7 \%$ & $90,0 \%$ & 750,10 & $8,7 \%$ & $10,9 \%$ & $63,9 \%$ & $-\quad 283,50$ \\
\hline 6) Machinery and Transport & 181,70 & $16,5 \%$ & $3,4 \%$ & $93,4 \%$ & $1.948,20$ & $21,3 \%$ & $28,2 \%$ & $92,1 \%$ & $-1.766,50$ \\
\hline 7) Miscellaneous & 294,80 & $5,9 \%$ & $5,5 \%$ & $98,9 \%$ & 545,00 & $18,0 \%$ & $7,9 \%$ & $100,0 \%$ & $-\quad 250,20$ \\
\hline 8) Others & 59,70 & $8,6 \%$ & $1,1 \%$ & $100,0 \%$ & - & $0,0 \%$ & $0,0 \%$ & $100,0 \%$ & 59,70 \\
\hline Total & $5.385,50$ & $12,1 \%$ & $100,0 \%$ & & $6.906,70$ & $15,5 \%$ & $100,0 \%$ & & $-1.521,20$ \\
\hline
\end{tabular}

Source: UNO Comtrade, disp in: http://comtrade.un.org/pb/CountryPagesNew.aspx?y=2009

Value in Million US\$

Quadro 6: Balança comercial do Uruguai em 2009 


\begin{tabular}{|c|c|c|c|c|c|c|c|}
\hline \multirow{2}{*}{$\begin{array}{l}\text { Rio Grande do Sul } \\
\text { - Balance of Trade }\end{array}$} & \multicolumn{3}{|c|}{ EXPORTS (FOB) } & \multicolumn{3}{|c|}{ IMPORTS (CIF) } & \multirow[b]{2}{*}{ Balance } \\
\hline & $\begin{array}{l}\text { Value } \\
2009\end{array}$ & $\begin{array}{l}2009 \\
\text { share }\end{array}$ & $\begin{array}{c}\text { Cumulated } \\
\text { share }\end{array}$ & $\begin{array}{l}\text { Value } \\
2009\end{array}$ & $\begin{array}{l}2009 \\
\text { share }\end{array}$ & $\begin{array}{c}\text { Cumulated } \\
\text { share }\end{array}$ & \\
\hline 1) Food & $5.376,0$ & $35,3 \%$ & $35,3 \%$ & 441,8 & $4,7 \%$ & $4,7 \%$ & $4.934,2$ \\
\hline 2) Crude Material & $2.573,3$ & $16,9 \%$ & $52,2 \%$ & 177,5 & $1,9 \%$ & $6,5 \%$ & $2.395,9$ \\
\hline 3) Fuel and oils & $1.756,8$ & $11,5 \%$ & $63,7 \%$ & $3.469,5$ & $36,6 \%$ & $43,2 \%$ & $-1.712,7$ \\
\hline 4) Chemical & $1.363,6$ & $8,9 \%$ & $72,7 \%$ & $1.494,5$ & $15,8 \%$ & $59,0 \%$ & $-130,9$ \\
\hline 5) Manufactured Goods & $1.030,3$ & $6,8 \%$ & $79,4 \%$ & 680,5 & $7,2 \%$ & $66,1 \%$ & 349,8 \\
\hline 6) Machinery and Transport & $1.637,3$ & $10,7 \%$ & $90,2 \%$ & $2.953,5$ & $31,2 \%$ & $97,3 \%$ & $-1.316,2$ \\
\hline 7) Miscellaneous & $1.498,7$ & $9,8 \%$ & $100,0 \%$ & 252,9 & $2,7 \%$ & $100,0 \%$ & $1.245,8$ \\
\hline 8) Others & 0,0 & $0,0 \%$ & $100,0 \%$ & 0,0 & $0,0 \%$ & $100,0 \%$ & \\
\hline 9) Total & $15.236,1$ & $100,0 \%$ & & $9.470,1$ & $100,0 \%$ & & $5.765,9$ \\
\hline
\end{tabular}

\begin{tabular}{|l|l|l|l|l|l|l}
\hline Sourse: http://aliceweb.desenvolvimento.gov.br/ & Value in Million US\$
\end{tabular} Obs: Para elaboração da tabela foi compatibilizado a nomenclatura do HS07 para seu correspondente em SITC rev. 4

O valor em US\$ das exportações totais cresceu 9,8\% a.a. entre 2005 e 2009 e as importações 9,1\% a.a.

Quadro 7: Balança Comercial do Rio Grande do Sul com países estrangeiros em 2009 


\begin{tabular}{|c|c|c|c|c|c|c|c|c|c|c|c|c|c|c|}
\hline \multirow[b]{2}{*}{ Território } & \multicolumn{2}{|c|}{ Animais Vivos } & \multicolumn{2}{|c|}{ Came Bovina } & \multicolumn{2}{|c|}{ Outras Cames } & \multicolumn{2}{|c|}{ Leite } & \multicolumn{2}{|c|}{ Manteiga } & \multicolumn{2}{|c|}{ Queijos } & \multicolumn{2}{|l|}{ Lã } \\
\hline & $\begin{array}{l}\text { Valor } \\
\text { Export. } \\
\text { Média } \\
08 / 09\end{array}$ & \begin{tabular}{|c|} 
Rank \\
país \\
08/09
\end{tabular} & $\begin{array}{l}\text { Valor } \\
\text { Export. } \\
\text { Média } \\
\text { 08/09 }\end{array}$ & $\begin{array}{c}\text { Rank } \\
\text { país } \\
\text { 08/09 }\end{array}$ & $\begin{array}{l}\text { Valor } \\
\text { Export. } \\
\text { Média } \\
\text { 08/09 }\end{array}$ & \begin{tabular}{|c|} 
Rank \\
país \\
$08 / 09$
\end{tabular} & $\begin{array}{l}\text { Valor } \\
\text { Export. } \\
\text { Média } \\
08 / 09\end{array}$ & $\begin{array}{c}\text { Rank } \\
\text { país } \\
08 / 09\end{array}$ & $\begin{array}{l}\text { Valor } \\
\text { Export. } \\
\text { Média } \\
\text { 08/09 }\end{array}$ & $\begin{array}{c}\text { Rank } \\
\text { país } \\
08 / 09\end{array}$ & $\begin{array}{l}\text { Valor } \\
\text { Export. } \\
\text { Média } \\
08 / 09\end{array}$ & $\begin{array}{c}\text { Rank } \\
\text { país } \\
08 / 09\end{array}$ & $\begin{array}{c}\text { Valor } \\
\text { Export. } \\
\text { Média } \\
08 / 09\end{array}$ & $\begin{array}{c}\text { Rank } \\
\text { país } \\
08 / 09\end{array}$ \\
\hline Mundo & $17.271,15$ & & $30.561,85$ & & $56.507,45$ & & $31.971,85$ & & $5.393,15$ & & $24.725,25$ & & $4.682,80$ & \\
\hline Austrália & 923,00 & $5 / 5$ & $3.780,87$ & $1 / 1$ & $1.782,82$ & $11 / 11$ & $1.122,60$ & $7 / 7$ & 175,50 & $10 / 9$ & 655,53 & $9 / 10$ & $1.693,10$ & $1 / 1$ \\
\hline AUS\% Mundo & $5,34 \%$ & $5 / 5$ & $12,34 \%$ & $1 / 1$ & $3,16 \%$ & $11 / 11$ & $3,50 \%$ & $7 / 7$ & $3,31 \%$ & $10 / 9$ & $2,63 \%$ & $9 / 10$ & $36,20 \%$ & $1 / 1$ \\
\hline Nova Zelândia & 124,34 & $x$ & $1.237,67$ & $8 / 9$ & $2.211,62$ & $10 / 10$ & $3.749,35$ & $2 / 2$ & $1.081,25$ & $1 / 1$ & 994,84 & $6 / 6$ & 462,78 & $3 / 3$ \\
\hline NZ\% Mundo & $0,72 \%$ & $x$ & $4,04 \%$ & $8 / 9$ & $3,92 \%$ & $10 / 10$ & $11,73 \%$ & $2 / 2$ & $20,04 \%$ & $1 / 1$ & $4,00 \%$ & $6 / 6$ & $9,91 \%$ & $3 / 3$ \\
\hline Brasil & 444,36 & $12 / 10$ & $3.514,41$ & $2 / 2$ & $7.578,09$ & $2 / 2$ & 293,74 & $x$ & 9,07 & $x$ & 25,73 & $x$ & 28,16 & $x$ \\
\hline BR\% Mundo & $2,58 \%$ & $12 / 10$ & $11,44 \%$ & $2 / 2$ & $13,38 \%$ & $2 / 2$ & $0,86 \%$ & $x$ & $0,16 \%$ & $x$ & $0,10 \%$ & $x$ & $0,61 \%$ & $x$ \\
\hline Argentina & 35,00 & $x$ & $1.449,36$ & $7 / 7$ & 546,48 & $x$ & 513,20 & $15 / 14$ & 58,18 & $x$ & 160,04 & $x$ & 178,84 & $7 / 8$ \\
\hline ARG\% Mundo & $0,20 \%$ & $x$ & $4,78 \%$ & $7 / 7$ & $0,97 \%$ & $x$ & $1,61 \%$ & $15 / 14$ & $1,04 \%$ & $x$ & $0,65 \%$ & $x$ & $3,80 \%$ & $7 / 8$ \\
\hline Uruguay & 76,22 & $x$ & $1.072,86$ & $9 / 12$ & 133,83 & $x$ & 219,99 & $x$ & 37,26 & $x$ & 139,82 & $x$ & 190,08 & $9 / 7$ \\
\hline URU\% Mundo & $0,44 \%$ & $x$ & $3,50 \%$ & $9 / 12$ & $0,24 \%$ & $x$ & $0,69 \%$ & $x$ & $0,71 \%$ & $x$ & $0,57 \%$ & $x$ & $4,10 \%$ & $9 / 7$ \\
\hline Rio Grande do Sul & 7,75 & $x$ & 86,88 & $x$ & $1.876,33$ & $x$ & 32,88 & $x$ & 8,13 & $x$ & 1,34 & $x$ & 19,80 & $x$ \\
\hline RS \% Mundo & $0,04 \%$ & $x$ & $1,29 \%$ & $x$ & $3,31 \%$ & $x$ & $0,61 \%$ & $x$ & $0,15 \%$ & $\mathrm{x}$ & $0,01 \%$ & $x$ & $0,44 \%$ & $x$ \\
\hline
\end{tabular}

Fonte: ONU - Comtrade. Disp. em http://comtrade.un.org

Value in Millon US\$

Aliceweb-MDIC Disp. em http://aliceweb.desenvolvimento.gov.br

Quadro 8: Exportações de produtos da bovinoculutura e ovinocultura de cinco países selecionados e do Rio Grande do Sul

(valores médios para 2008/2009, com o ranking entre os 15 maiores exportadores nos dois anos) 


\begin{tabular}{|c|r|r|r|}
\hline \multicolumn{4}{|c|}{ Exportações 2009 (em US\$ 1000) } \\
\hline Países & $\begin{array}{c}\text { Valor Total em US\$ } \\
1000\end{array}$ & $\begin{array}{c}\text { Valor Prod Selec } \\
\text { (Derivados Bovino } \\
\text { e Ovino) }\end{array}$ & $\begin{array}{c}\text { \% Valor Prod } \\
\text { Selec no Total }\end{array}$ \\
\hline Austrália & $153.766,56$ & $9.171,39$ & $6,0 \%$ \\
\hline Nova Zelândia & $24.932,60$ & $8.807,52$ & $35,3 \%$ \\
\hline Brasil & $152.994,74$ & $10.541,16$ & $6,9 \%$ \\
\hline Argentina & $55.669,06$ & $2.886,77$ & $5,2 \%$ \\
\hline Uruguai & $5.385,51$ & $1.713,86$ & $31,8 \%$ \\
\hline Rio Grande do Sul & $15.236,06$ & $1.741,72$ & $11,4 \%$ \\
\hline
\end{tabular}

Fontes: 1) ONU-Comtrade. Disp. em: http://comtrade.un.org/db/

2) Aliceweb-MDIC Disp. em http://aliceweb.desenvolvimento.gov.br

Quadro 9: Participação das exportações pecuárias selecionadas na balança comercial dos países do Mercosul e da Oceania e do Rio Grande do Sul 


\begin{tabular}{|c|c|c|c|c|c|c|c|c|}
\hline \multicolumn{2}{|c|}{ Setores } & \begin{tabular}{|c|} 
Importação de \\
Bens \\
e Serviços \\
Internacional \\
\end{tabular} & $\begin{array}{c}\text { Exportação de } \\
\text { Bens } \\
\text { e Serviços } \\
\text { Internacional }\end{array}$ & $\begin{array}{c}\text { Saldo Balança } \\
\text { Comercial } \\
\text { Externa }\end{array}$ & $\begin{array}{c}\text { Importação } \\
\text { de Bense } \\
\text { Serviços } \\
\text { Interestadual }\end{array}$ & \begin{tabular}{|c|} 
Exportação \\
de Bense \\
Serviços \\
Interestadual \\
\end{tabular} & $\begin{array}{l}\text { Saldo Balança } \\
\text { Comercial } \\
\text { Interestadual }\end{array}$ & $\begin{array}{c}\text { Saldo Balança } \\
\text { Comercial } \\
\text { Total }\end{array}$ \\
\hline \multirow{4}{*}{$\begin{array}{l}\text { Agroindústria } \\
\text { "Neozelandesa" }\end{array}$} & Lácteos & $-53,67$ & 8,16 & $-45,50$ & $-736,28$ & $1.011,46$ & 275,17 & 229,67 \\
\hline & Carnes & $-60,86$ & $2.318,96$ & $2.258,09$ & $-1.312,71$ & $3.807,27$ & $2.494,56$ & $4.752,65$ \\
\hline & Bebidas & $-81,79$ & 21,98 & $-59,81$ & $-264,88$ & $1.832,65$ & $1.567,78$ & $1.507,96$ \\
\hline & Tex, Ves, Cal & $-522,27$ & $5.150,99$ & $4.628,71$ & $-3.762,78$ & $4.828,95$ & $1.066,17$ & $5.694,88$ \\
\hline \multirow{4}{*}{$\begin{array}{c}\text { Outras } \\
\text { Agroindústrias }\end{array}$} & Grãos e óleos & $-751,77$ & $4.358,48$ & $3.606,71$ & $-1.354,69$ & $11.134,19$ & $9.779,51$ & $13.386,22$ \\
\hline & Fumo & $-62,85$ & $2.893,09$ & $2.830,24$ & $-358,10$ & $1.566,21$ & $1.208,10$ & $4.038,34$ \\
\hline & Mad, Mob, Cel & $-324,56$ & $1.313,30$ & 988,74 & $-3.656,39$ & $2.855,78$ & $-800,60$ & 188,14 \\
\hline & Outras Agroalim & $-226,83$ & 393,25 & 166,42 & $-3.975,72$ & $3.308,12$ & $-667,61$ & $-501,19$ \\
\hline \multicolumn{2}{|c|}{ Ext Min, Metal, Mec, Mat Trans } & $-7.353,02$ & $4.674,78$ & $-2.678,24$ & $-22.879,29$ & $16.298,33$ & $-6.580,97$ & $-9.259,21$ \\
\hline \multicolumn{2}{|c|}{ Borracha, Química e Plástico } & $-3.882,01$ & $2.969,27$ & $-912,74$ & $-12.518,74$ & $9.167,97$ & $-3.350,77$ & $-4.263,51$ \\
\hline \multicolumn{2}{|c|}{ Produtos Diversos } & $-209,53$ & 219,60 & 10,07 & $-1.567,74$ & $1.027,82$ & $-539,92$ & $-529,85$ \\
\hline \multicolumn{2}{|c|}{ SIUP } & $-1.429,00$ & 0,00 & $-1.429,00$ & $-1.638,64$ & $1.152,92$ & $-485,72$ & $-1.914,72$ \\
\hline \multicolumn{2}{|c|}{ Construção Civil } & 0,00 & 0,00 & 0,00 & $-59,05$ & 9,61 & $-49,44$ & $-49,44$ \\
\hline \multicolumn{2}{|c|}{ Comércio, Serviços e Adm Pub } & $-0,01$ & 122,84 & 122,84 & $-3.151,80$ & $2.403,05$ & $-748,75$ & $-625,91$ \\
\hline \multicolumn{2}{|c|}{ TOTAL } & $-14.284,18$ & $24.444,71$ & $9.486,53$ & $-57.236,82$ & $60.404,32$ & $3.167,50$ & $12.654,03$ \\
\hline
\end{tabular}

Fonte: Matriz de Insumo Produto RS / 2003 (2007); FEE. Disp. em: http://www.fee.tche.br/sitefee/pt/content/estatisticas/mip-rs-2003/index.htm Valores em R\$̣ de 2003

Quadro 10: Balança comercial internacional e interestadual do RS em 2003 


\begin{tabular}{|c|c|c|c|c|c|c|c|c|c|c|c|}
\hline \multicolumn{2}{|c|}{ Setores } & $\begin{array}{c}\text { SaldbBalança } \\
\text { Comercial } \\
\text { Totd }\end{array}$ & $\begin{array}{c}\text { Consumo } \\
\text { da } \\
\text { Adhinistracão } \\
\text { Pública }\end{array}$ & $\begin{array}{c}\text { Consumo } \\
\text { desFańlias }\end{array}$ & $\begin{array}{c}\text { Formação } \\
\text { Buta } \\
\text { deCapita Fxo }\end{array}$ & $\begin{array}{l}\text { Variação } \\
\text { deEstoque }\end{array}$ & $\begin{array}{c}\text { Derrenda } \\
\text { Find }\end{array}$ & $\begin{array}{l}\text { Derranda } \\
\text { Tota }\end{array}$ & $\begin{array}{l}\text { Contribuição } \\
\text { peraoPIB }\end{array}$ & $\begin{array}{c}\text { Contribuição\% } \\
\text { noPIB }\end{array}$ & $\begin{array}{c}\text { Contribuição\% } \\
\text { noPlB } \\
\text { (Aamlada) }\end{array}$ \\
\hline \multirow{4}{*}{$\begin{array}{l}\text { Agrindístria } \\
\text { "Neordandesd" }\end{array}$} & Lácteos & 229,6 & $0, \infty$ & 1529,61 & 0,00 & 32,24 & 2581,47 & $4.838,20$ & 1791,52 & $1,37 \%$ & $1,37 \%$ \\
\hline & Carmes & $4.752,65$ & $0, \infty$ & $3.448,24$ & 34,65 & 617,70 & $10.226,82$ & $18.317,14$ & $8.853,24$ & $6,76 \%$ & $8,12 \%$ \\
\hline & Bebiclas & 1507,96 & $0, \infty$ & 1792,06 & 0,00 & 36,45 & $3.683,14$ & $5.110,79$ & $3.336,47$ & $2,55 \%$ & $10,6 \%$ \\
\hline & Tex, Ves, Cal & $5.694,88$ & $0, \infty$ & $3.683,00$ & 0,00 & 144,06 & $13.807,00$ & $18.400,86$ & $9.521,94$ & $7,27 \%$ & $17,93 \%$ \\
\hline \multirow{4}{*}{$\begin{array}{c}\text { Qtros } \\
\text { Agraindístrias }\end{array}$} & Gãoseóleos & $13.386,22$ & $0, \infty$ & 1326,11 & 0,00 & 2598,41 & $19.417,20$ & $31.486,03$ & $17.310,74$ & $13,21 \%$ & $31,14 \%$ \\
\hline & Fumo & 4.038,34 & $0, \infty$ & 937,79 & 0,00 & 73,27 & $5.470,36$ & $7.712,95$ & $5.049,40$ & $3,85 \%$ & $35,00 \%$ \\
\hline & Nad, Nab, Cel & 188,14 & $0, \infty$ & 2054,95 & 571,12 & $-8,67$ & $6.786,49$ & 12851,00 & 2805,54 & $2,14 \%$ & $37,14 \%$ \\
\hline & OtrasAgroalim & $-501,19$ & $0, \infty$ & $5.491,40$ & 140,08 & 46,24 & $9.379,09$ & $15.686,78$ & $5.176,54$ & $3,95 \%$ & $41,09 \%$ \\
\hline \multicolumn{2}{|c|}{ ExtMn, Metd, Mec, Mat Trans } & $-9.259,21$ & $0, \infty$ & $8.070,68$ & $10.104,91$ & 360,71 & $39.509,42$ & $69.632,97$ & $9.277,10$ & $7,08 \%$ & $48,17 \%$ \\
\hline \multicolumn{2}{|c|}{ Borrada, QúmicaePlástico } & $-4.263,51$ & $0, \infty$ & $9.028,05$ & 0,00 & 34,92 & 21200,21 & $66.899,70$ & 4.799,46 & $3,66 \%$ & $51,83 \%$ \\
\hline \multicolumn{2}{|c|}{ ProdutosDiversos } & $-529,85$ & $0, \infty$ & 866,49 & 226,39 & 4,90 & 2345,21 & $3.510,02$ & 567,93 & $0,43 \%$ & $52,26 \%$ \\
\hline \multicolumn{2}{|c|}{ SUP } & $-1914,72$ & $0, \infty$ & 2468,20 & 0,00 & 0,00 & $3.621,12$ & $9.156,84$ & 553,48 & $0,42 \%$ & $52,68 \%$ \\
\hline \multicolumn{2}{|c|}{ ConstruçãoGivil } & $-49,44$ & $0, \infty$ & 0,00 & $5.170,89$ & 0,00 & $5.180,50$ & $7.543,00$ & $5.121,45$ & $3,91 \%$ & $56,59 \%$ \\
\hline \multicolumn{2}{|c|}{ Comércio, SeniçoseAdmPub } & $-625,91$ & 21490,84 & $35.217,06$ & 131,64 & 0,00 & $59.365,44$ & 88861,91 & $56.213,64$ & $42,89 \%$ & $100,00 \%$ \\
\hline \multicolumn{2}{|c|}{ TOAL } & 12654,08 & 21490,84 & $75.913,66$ & $16.379,68$ & $3.940,24$ & 202573,46 & $360.008,18$ & 131053,46 & $100,00 \%$ & $x$ \\
\hline
\end{tabular}

Fonte: NatrizdelnsumoProdutoRS/2003(2007); 㞋 Disp em http://wuwfeetchelor/sitefee/pt/contert/estatisticas/miprs-2003/indexhtm

Valores emR\$́de2003

Quadro 11: Contribuição de setores econômicos selecionados para o PIB do RS em 2003 


\begin{tabular}{|c|c|c|c|c|c|c|c|c|c|c|c|c|}
\hline Território & & Bras & & & & Rio Gran & de do Sul & & \% ou Q & lquocient & e locacional) & RS no BR \\
\hline Variáve is & Total & Pecuária & $\begin{array}{l}\text { Lavoura } \\
\text { temporária }\end{array}$ & Outros & Total & Pecuária & $\begin{array}{c}\text { Lavoura } \\
\text { temporária }\end{array}$ & Outros & Total & Pecuária & \begin{tabular}{|c|} 
Lavoura \\
temporária
\end{tabular} & Outros \\
\hline $\begin{array}{c}\text { Número de Estab } \\
\text { Agropec }\end{array}$ & 5.175 .489 & 2.277 .214 & 1.908 .650 & 989.625 & 441.467 & 167.701 & 221.476 & 52.290 & $8,53 \%$ & $7,36 \%$ & $11,60 \%$ & $5,28 \%$ \\
\hline $\begin{array}{c}\text { Área dos Estab } \\
\text { Agropec (Ha) }\end{array}$ & 329.941 .393 & 204.442 .686 & 83.464 .327 & 42.034 .381 & 20.199 .489 & 8.883 .511 & 9.716 .580 & 1.599 .399 & $6,12 \%$ & $4,35 \%$ & $11,64 \%$ & $3,80 \%$ \\
\hline $\begin{array}{l}\text { Número de Estab } \\
\text { Prod leite } 2006\end{array}$ & 1.349 .326 & 971.373 & 279.467 & 98.486 & 205.158 & 100.745 & 93.046 & 11.367 & $15,20 \%$ & $10,37 \%$ & $33,29 \%$ & $11,54 \%$ \\
\hline \begin{tabular}{|c|} 
\% Estabelecimentos \\
Prod Leite no Total
\end{tabular} & $26,07 \%$ & $42,66 \%$ & $14,64 \%$ & $9,95 \%$ & $46,47 \%$ & $60,07 \%$ & $42,01 \%$ & $21,74 \%$ & 1,78 & 1,41 & 2,87 & 2,18 \\
\hline $\begin{array}{c}\text { Vacas ordenhadas } \\
\text { (cabeças) }\end{array}$ & 12.636 .548 & 10.464 .915 & 1.539 .904 & 631.729 & 981.769 & 608.024 & 342.936 & 30.809 & $7,77 \%$ & $5,81 \%$ & $22,27 \%$ & $4,88 \%$ \\
\hline \begin{tabular}{|c|} 
Quantidade \\
Produzida (Mil litros)
\end{tabular} & 20.157 .682 & 16.968 .098 & 2.388 .630 & 800.953 & 2.455 .611 & 1.725 .417 & 676.807 & 53.386 & $12,18 \%$ & $10,17 \%$ & $28,33 \%$ & $6,67 \%$ \\
\hline $\begin{array}{c}\text { Produção média por } \\
\text { vaca dia (litros) }\end{array}$ & 4,37 & 4,44 & 4,25 & 3,47 & 6,85 & 7,77 & 5,41 & 4,75 & 1,57 & 1,75 & 1,27 & 1,37 \\
\hline \begin{tabular}{|c|}
$\begin{array}{c}\text { Valor da produção de } \\
\text { leite (Mil Reais) }\end{array}$ \\
\end{tabular} & 8.817 .536 & 7.458 .245 & 998.974 & 360.316 & 1.001 .258 & 713.128 & 265.548 & 22.581 & $11,36 \%$ & $9,56 \%$ & $26,58 \%$ & $6,27 \%$ \\
\hline \begin{tabular}{|c|} 
Quantidade vendida \\
(Mil litros)
\end{tabular} & 18.381 .354 & 15.536 .923 & 2.140 .772 & 703.659 & 2.272 .581 & 1.622 .905 & 605.320 & 44.355 & $12,36 \%$ & $10,45 \%$ & $28,28 \%$ & $6,30 \%$ \\
\hline $\begin{array}{l}\text { Venda média por } \\
\text { vaca dia (litros) }\end{array}$ & 3,985 & 4,068 & 3,809 & 3,052 & 6,342 & 7,313 & 4,836 & 3,944 & 1,59 & 1,80 & 1,27 & 1,29 \\
\hline $\begin{array}{l}\text { Valor da venda } \\
\text { (Mil Reais) }\end{array}$ & 7.940 .414 & 6.748 .346 & 881.312 & 310.755 & 916.463 & 664.997 & 233.222 & 18.244 & $11,54 \%$ & $9,85 \%$ & $26,46 \%$ & $5,87 \%$ \\
\hline $\begin{array}{c}\text { Num estab com } \\
\text { tanques para leite }\end{array}$ & 145.595 & 103.907 & 37.220 & 762.363 & 45.699 & 29.152 & 15.687 & 860 & $31,39 \%$ & $28,06 \%$ & $42,15 \%$ & $0,11 \%$ \\
\hline $\begin{array}{l}\text { Capacidade dos } \\
\text { tanques (Mil lits) }\end{array}$ & 115.297 & 88.895 & 21.683 & 762.276 & 21.743 & 14.335 & 6.584 & 825 & $18,86 \%$ & $16,13 \%$ & $30,36 \%$ & $0,11 \%$ \\
\hline
\end{tabular}

Fonte: Censo Agropecuária 2006. Acessado via Sidra. Disp. Em: http://www.sidra.ibge.gov.br/bda/acervo/acervo2.asp?e=v\&p=CA\&z=t\&o=11

Quadro 12: A produção de leite vacum do Rio Grande do Sul em relação ao Brasil 


\begin{tabular}{|c|c|c|c|c|c|c|c|c|c|c|c|c|c|c|c|c|c|c|c|c|c|c|c|}
\hline \multirow[b]{2}{*}{ Sistemas } & \multirow[b]{2}{*}{ Cenários } & \multicolumn{7}{|c|}{ Matrizes com Xanos } & \multicolumn{5}{|c|}{ Novilhos(as) } & \multicolumn{3}{|c|}{ Rebanho } & \multicolumn{4}{|c|}{ abate } & \multicolumn{3}{|c|}{ Desfrute e Produtividade } \\
\hline & & 3 & 4 & 5 & 6 & 7 & 8 & Total & $\begin{array}{c}\text { nova } \\
1\end{array}$ & \begin{tabular}{|c|} 
nova \\
2
\end{tabular} & $\begin{array}{c}\text { novo } \\
1\end{array}$ & \begin{tabular}{|c|} 
novo \\
2
\end{tabular} & Total & touros & $\begin{array}{l}\text { Mat + } \\
\text { touros }\end{array}$ & Total & novo & nova & matriz & total & $\begin{array}{l}\text { Abate / } \\
\text { plantel }\end{array}$ & $\begin{array}{c}\text { Abate / } \\
\text { Tou + Mat }\end{array}$ & Nov / Reb \\
\hline \multirow{4}{*}{ Tradicional } & Ruim & 87 & 78 & 70 & 63 & 57 & 51 & 407 & 102 & 92 & 102 & 92 & 315 & 20 & 427 & 1200 & 92 & 92 & 51 & 234 & $19,53 \%$ & $54,86 \%$ & $32,2 \%$ \\
\hline & Razoável & 77 & 69 & 62 & 56 & 50 & 45 & 360 & 126 & 114 & 126 & 114 & 384 & 18 & 378 & 1200 & 114 & 114 & 45 & 272 & $22,70 \%$ & $72,00 \%$ & $39,9 \%$ \\
\hline & Bom & 60 & 57 & 54 & 51 & 49 & 46 & 318 & 143 & 139 & 143 & 139 & 433 & 8 & 326 & 1200 & 139 & 139 & 46 & 324 & $27,01 \%$ & $99,42 \%$ & $47,0 \%$ \\
\hline & Excelente & 53 & 52 & 51 & 50 & 49 & 48 & 302 & 150 & 148 & 150 & 148 & 453 & 5 & 307 & 1200 & 148 & 148 & 48 & 344 & $28,68 \%$ & $111,99 \%$ & $49,6 \%$ \\
\hline \multicolumn{2}{|c|}{ Integrado } & 0 & 0 & 0 & 0 & 0 & 0 & 0 & 226 & 224 & 375 & 373 & 1200 & 0 & 0 & 1200 & 224 & 373 & 0 & 597 & $49,75 \%$ & $\bar{X}$ & $100 \%$ \\
\hline
\end{tabular}

Quadro 13: Estrutura e produtividade física de distintos sistemas de pecuária de corte em distintos cenários

\begin{tabular}{|c|l|c|c|c|c|c|c|}
\hline \multirow{3}{*}{ Sistemas } & \multirow{2}{*}{ Cenários } & \multicolumn{7}{|c|}{ Retorno Econômico } \\
\cline { 3 - 8 } & & $\begin{array}{c}\text { Valor } \\
\text { abate }\end{array}$ & $\begin{array}{c}\text { Valor do } \\
\text { plantel }\end{array}$ & $\begin{array}{c}\text { Abate / } \\
\text { plantel }\end{array}$ & $\begin{array}{c}\text { Valor } \\
\text { Patrim }\end{array}$ & $\begin{array}{c}\text { Abate / } \\
\text { Patrim }\end{array}$ & $\begin{array}{c}\text { Var } \\
\text { Aba/Patr }\end{array}$ \\
\hline \multirow{3}{*}{ Tradicional } & Ruim & 190 & 624 & $30 \%$ & 3.624 & $5,25 \%$ & X \\
\cline { 2 - 8 } & Razoável & 227 & 637 & $36 \%$ & 3.637 & $6,24 \%$ & $18,82 \%$ \\
\cline { 2 - 8 } & Bom & 273 & 607 & $45 \%$ & 3.607 & $7,57 \%$ & $21,26 \%$ \\
\cline { 2 - 8 } & Excelente & 291 & 601 & $48 \%$ & 3.601 & $8,07 \%$ & $6,63 \%$ \\
\hline \multirow{2}{*}{ Integrado } & Preço Eq & 552 & 775 & $71 \%$ & 3.775 & $14,63 \%$ & $81,27 \%$ \\
\cline { 2 - 8 } & Preço 50\% & 273 & 383 & $71 \%$ & 3.383 & $8,07 \%$ & $-44,83 \%$ \\
\hline
\end{tabular}

Quadro 14: Produtividade econômica de distintos sistemas de pecuária de corte em distintos cenários 


\begin{tabular}{|c|c|c|c|c|c|}
\hline \multirow{2}{*}{$\begin{array}{l}\text { Estabelecimentos por } \\
\text { Especialização Produtiva }\end{array}$} & \multicolumn{3}{|c|}{ Área (em Km 2) } & \multirow{2}{*}{$\begin{array}{l}\text { Número de } \\
\text { Estab }\end{array}$} & \multirow{2}{*}{$\begin{array}{l}\text { Área Média } \\
\text { (em ha) }\end{array}$} \\
\hline & Total & Pastagens & Outras & & \\
\hline Todos os Estabelecimentos Agropec & $147.008,97$ & $109.866,23$ & $37.142,74$ & 63.345 & 232,08 \\
\hline Pecuários & $121.832,99$ & $105.279,04$ & $16.553,95$ & 43.455 & 280,37 \\
\hline Bovino Leite & $20.164,21$ & $18.067,40$ & $2.096,81$ & 12.084 & 166,87 \\
\hline Bovino Corte & $18.137,25$ & $14.827,05$ & $3.310,20$ & 12.825 & 141,42 \\
\hline Ovinocultura & $76.966,86$ & $67.078,07$ & $9.888,79$ & 13.035 & 590,46 \\
\hline Outras Pecuárias & $6.564,67$ & $5.306,52$ & $1.258,15$ & 5.511 & 119,12 \\
\hline Agrícolas & $25.175,98$ & $4.383,89$ & $20.792,09$ & 19.890 & 126,58 \\
\hline Agricultura Temporária & $2.781,39$ & $1.331,09$ & $1.450,30$ & 2.334 & 119,17 \\
\hline Horticultura e Agric Perm & $2.409,60$ & 790,54 & $1.619,06$ & 10.650 & 22,63 \\
\hline Expl Florestal e outras atividades & $19.984,99$ & $2.262,26$ & $17.722,73$ & 6.906 & 289,39 \\
\hline
\end{tabular}

Fonte Agricultural Census 2007 - New Zealand. Disponível em:

http://www.stats.govt.nz/browse for stats/industry sectors/agriculture-horticulture-forestry/2007-agricultural-census-tables.as

Quadro 15: Características dos estabelecimentos agropecuários na Nova Zelândia 


\begin{tabular}{|c|c|c|c|c|c|c|c|c|c|c|c|c|c|c|c|}
\hline Plante & & Plantel Bo & xinoleite & & & Plant & tel BoinoC & & & & & Plantel & & & \\
\hline $\begin{array}{l}\text { Especialização } \\
\text { Produtivado } \\
\text { Estabelecimento } \\
\end{array}$ & $\begin{array}{c}\text { Vacas } \\
\text { Ordenhadas }\end{array}$ & $\begin{array}{l}\text { Nbvilhase } \\
\text { Nbvilhos }\end{array}$ & $\begin{array}{c}\text { Tarose } \\
\text { Boinos de } \\
\text { trabalho }\end{array}$ & Sub-Total & $\begin{array}{l}\text { Vacase } \\
\text { Nbuilhas }\end{array}$ & $\begin{array}{c}\text { Baise } \\
\text { Nbuilhos }\end{array}$ & \begin{tabular}{|c|} 
Tarose \\
Bainosde \\
trabalho
\end{tabular} & $\begin{array}{l}\text { Relação } \\
\text { Madcho/ } \\
\text { Fêrea }\end{array}$ & Sub-Total & $\begin{array}{l}\text { Boino } \\
\text { Tota }\end{array}$ & $\begin{array}{l}\text { Oinos } \\
\text { (Lã/Came) }\end{array}$ & \begin{tabular}{|c|} 
arimisce \\
grandee \\
médoparte
\end{tabular} & $\begin{array}{l}\text { Arima } \\
\text { (450kgs) }\end{array}$ & $\begin{array}{c}\text { Etabded } \\
\text { mentos }\end{array}$ & $\begin{array}{l}\text { Arim } \\
\text { porth }\end{array}$ \\
\hline Bovinoleite & 3.553 .410 & 537.102 & 44.302 & 4.134.814 & 64.480 & 139.460 & 7.870 & $228 \%$ & 211809 & 4.346 .623 & 38267 & 28.265 & 4.424.535 & 20.164 & 2,19 \\
\hline BovinoCorte & 272085 & 296.306 & 17.460 & 585.851 & 495.096 & 871111 & 27.530 & $182 \%$ & 1393.737 & 1979.588 & 925.430 & 29.683 & 2148668 & 18.137 & 1,18 \\
\hline Qinoaltura & 179.468 & 121893 & 5.954 & 307.315 & 1312180 & 1170.673 & 41243 & $92 \%$ & 2524.095 & 2831410 & 34.690 .013 & 41031 & 8.633.594 & 76.967 & 1,12 \\
\hline OtrasAtividades & 162158 & 67.518 & 3.194 & 232870 & 112614 & 147.581 & 3.781 & $134 \%$ & 263.976 & 496.846 & 246235 & 46261 & 1138.574 & 31741 & 0,36 \\
\hline Total & 4.167.121 & 1022819 & 70.910 & 5.260 .850 & 1984.369 & 2328.824 & 80.424 & $121 \%$ & 4.393.617 & 9.654 .467 & 38.460 .477 & 561650 & 16.345 .372 & 147.009 & 1,11 \\
\hline
\end{tabular}

FonteAgrialtural Census 2007-NewZealand Disporivel em

http:/hwwstats.goutnz/brouse for stats/industry sectors/agialturehortialtureforestry/2007-agialtural-censustables.asp

Quadro 16: Estrutura da pecuária Neo-Zelandesa 


\begin{tabular}{|c|c|c|c|c|c|c|c|c|c|c|c|c|}
\hline $\begin{array}{l}\text { Unidade da } \\
\text { Federação }\end{array}$ & $\begin{array}{l}\text { Totalde } \\
\text { cabeças }\end{array}$ & Bezerras & Bezerros & Novilhas & Novilhos & $\begin{array}{c}\text { Vacas } \\
\text { (inclusive } \\
\text { novilhas } \\
\text { prenhe) }\end{array}$ & $\begin{array}{l}\text { Touros } \\
\text { (repro- } \\
\text { dutores) }\end{array}$ & $\begin{array}{c}\text { Boise } \\
\text { garrotes } \\
\text { paracorte }\end{array}$ & $\begin{array}{c}\text { Bois e } \\
\text { garrotes } \\
\text { para } \\
\text { trabalho }\end{array}$ & $\begin{array}{l}\text { Total de } \\
\text { Fêm eas s }\end{array}$ & $\begin{array}{l}\text { Totalde } \\
\text { Machos }\end{array}$ & \begin{tabular}{|} 
Re lação o \\
Macho / \\
Fêm ea
\end{tabular} \\
\hline Acre & 1473338 & 193195 & 169166 & 208384 & 155698 & 461379 & 40066 & 235216 & 10234 & 862958 & 610380 & $70,73 \%$ \\
\hline Alagoas & 494058 & 59609 & 57169 & 73707 & 65173 & 137750 & 23072 & 69574 & 8004 & 271066 & 222992 & $82,26 \%$ \\
\hline Am a pá & 47528 & 5271 & 4842 & 5845 & 5099 & 18953 & 1756 & 4744 & 1018 & 30069 & 17459 & $58,06 \%$ \\
\hline Amazonas & 956861 & 98134 & 93059 & 151774 & 144431 & 261890 & 52128 & 145617 & 9828 & 511798 & 445063 & $86,96 \%$ \\
\hline Bahia & 6448164 & 710837 & 703358 & 956283 & 878002 & 2034577 & 260576 & 847888 & 56643 & 3701697 & 2746467 & $74,19 \%$ \\
\hline Ce a rá & 889792 & 88517 & 82267 & 173678 & 165014 & 249919 & 32253 & 868001 & 11343 & 512114 & 377678 & $73,75 \%$ \\
\hline Distrito Federal & 56939 & 7208 & 6847 & 8905 & 5729 & 20204 & 1926 & 6065 & 55 & 36317 & 20622 & $56,78 \%$ \\
\hline Espírito Santo & 1353747 & 163120 & 155120 & 192202 & 182091 & 420194 & 28739 & 203803 & 8478 & 775516 & 578231 & $74,56 \%$ \\
\hline Goiás & 15805916 & 1767381 & 1591089 & 2496754 & 1816899 & 5093157 & 434433 & 2533559 & 72644 & 9357292 & 6448624 & $68,92 \%$ \\
\hline Maranhão & 4417902 & 524965 & 514578 & 664162 & 555237 & 1337451 & 170896 & 615523 & 35090 & 2526578 & 1891324 & $74,86 \%$ \\
\hline Mato Grosso & 18777745 & 2111317 & 2022000 & 2705409 & 2197109 & 6237559 & 499273 & 2921548 & 83530 & 11054285 & 7723460 & $69,87 \%$ \\
\hline Mato Grossodo Sul & 19570364 & 2006205 & 2014962 & 2550877 & 2314328 & 6267302 & 523527 & 3771637 & 121526 & 10824384 & 8745980 & $80,80 \%$ \\
\hline Minas Gerais & 14973906 & 1829102 & 1646548 & 2301090 & 1951578 & 4881034 & 330055 & 1949724 & 84775 & 9011226 & 5962680 & $66,17 \%$ \\
\hline Pará & 11969401 & 1328266 & 1279251 & 1735487 & 1412881 & 3834877 & 443295 & 1855558 & 79786 & 6898630 & 5070771 & $73,50 \%$ \\
\hline Paraíba & 525781 & 62541 & 59056 & 80879 & 70633 & 156457 & 24731 & 63551 & 7933 & 299877 & 225904 & $75,33 \%$ \\
\hline Paraná & 6209367 & 654949 & 632613 & 905155 & 835126 & 1856545 & 146843 & 1149357 & 28779 & 3416649 & 2792718 & $81,74 \%$ \\
\hline Pernambuco & 685070 & 83218 & 76415 & 99022 & 89722 & 206268 & 30898 & 86726 & 12801 & 388508 & 296562 & $76,33 \%$ \\
\hline Piauí & 670835 & 74108 & 67644 & 95055 & 77536 & 248695 & 27135 & 70762 & 9900 & 417858 & 252977 & $60,54 \%$ \\
\hline Rio de Janeiro & 1464730 & 180348 & 165807 & 185363 & 165628 & 461887 & 39871 & 255188 & 10638 & 827598 & 637132 & $76,99 \%$ \\
\hline Rio GrandedoNorte & 427939 & 52336 & 49210 & 62559 & 55840 & 129283 & 18732 & 50955 & 9024 & 244178 & 183761 & $75,26 \%$ \\
\hline Rio Grande do Sul & 7468267 & 799360 & 768148 & 950244 & 839914 & 2858186 & 152038 & 1070553 & 29824 & 4607790 & 2860477 & $62,08 \%$ \\
\hline Rondônia & 7702154 & 879728 & 819835 & 1127362 & 914033 & 2544345 & 156651 & 1241430 & 18770 & 4551435 & 3150719 & $69,22 \%$ \\
\hline Roraim a & 405048 & 44391 & 43382 & 52991 & 45841 & 125095 & 16109 & 72063 & 5176 & 222477 & 182571 & $82,06 \%$ \\
\hline Santa Catarina & 1177734 & 146761 & 132130 & 168461 & 140170 & 401374 & 31518 & 149693 & 7627 & 716596 & 461138 & $64,35 \%$ \\
\hline São Paulo & 8586178 & 944123 & 902284 & 1278645 & 1047578 & 2470283 & 216232 & 1686447 & 40586 & 4693051 & 3893127 & $82,96 \%$ \\
\hline Sergipe & 465722 & 51031 & 46666 & 65227 & 60129 & 134892 & 18851 & 81783 & 7143 & 251150 & 214572 & $85,44 \%$ \\
\hline Tocantins & 5469617 & 608369 & 552249 & 876085 & 647796 & 1930205 & 187272 & 579910 & 87731 & 3414659 & 2054958 & $60,18 \%$ \\
\hline Brasil & 138494103 & 15474390 & 14655695 & 20171605 & 16839215 & 44779761 & 3908876 & 21805675 & 858886 & 80425756 & 58068347 & $72,20 \%$ \\
\hline
\end{tabular}

Fonte: IBGE-Censo Agropecuário 2006 .

Quadro 17: Composição do efetivo de bovinos nos estabelecimentos com + de 50 cabeças em 31.12 .06 por UF 